\title{
Reconstruction of the musculoskeletal system in an extinct lion
}

\author{
Andrew R Cuff, Anjali Goswami, and John R. Hutchinson
}

\begin{abstract}
Panthera atrox is an extinct lion from the Pleistocene of North America that is one of the largest felids that has ever existed. Previous reconstructions have always relied on composite specimens, and there are no known specimens that preserve soft tissues. Here we present a reconstruction of the most complete $P$. atrox specimen discovered to date, from which we calculate key biological parameters including body mass. Using previously published scaling equations we estimate the size of the musculature of the limbs and vertebral column. Muscles from a modern lion were scaled to the expected sizes and placed on the skeleton. The body and the limbs were digitally reconstructed (using a convex hulling method) from the skeleton before this method was repeated with the muscled limb segments. Our results from repeating this approach for a modern lion show that the combined muscle and bone convex hull reconstructions are the most accurate for reproducing the limb dimensions, including centres of mass, of large felids. From the reconstructions it is also possible to estimate the body composition of $P$. atrox, which allows for the most complete soft tissue reconstruction of this extinct species, including biomechanical properties of the limbs.
\end{abstract}

Andrew R Cuff. Department of Genetics, Evolution and Environment, University College London, Darwin Building, Gower Street, London, WC1E 6BT, United Kingdom; Structure and Motion Lab, Department of Comparative Biomedical Sciences, The Royal Veterinary College, Hawkshead Lane, North Mymms, Hatfield, Herts, AL9 7TA, United Kingdom. acuff@rvc.ac.uk

Anjali Goswami. Department of Genetics, Evolution and Environment, University College London, Darwin Building, Gower Street, London, WC1E 6BT, United Kingdom. a.goswami@ucl.ac.uk

John R. Hutchinson. Structure and Motion Lab, Department of Comparative Biomedical Sciences, The Royal Veterinary College, Hawkshead Lane, North Mymms, Hatfield, Herts, AL9 7TA, United Kingdom; Department of Genetics, Evolution and Environment, University College London, Darwin Building, Gower Street, London, WC1E 6BT, United Kingdom. jhutchinson@rvc.ac.uk

Keywords: fossil reconstruction; muscles; Felidae; Panthera atrox; scaling

Submission: 3 June 2016 Acceptance: 1 May 2017

Cuff, Andrew R., Goswami, Anjali, and Hutchinson, John R. 2017. Reconstruction of the musculoskeletal system in an extinct lion. Palaeontologia Electronica 20.2.23A: 1-25

palaeo-electronica.org/content/2017/1857-reconstructing-a-fossil-lion 


\section{INTRODUCTION}

Soft tissues seldom are preserved during the fossilisation process, and, as such, most reconstructions of fossil taxa must be based, in terms of direct evidence, solely upon the skeletal remains. Those remains can be incredibly useful for reconstructing myology as the muscles often leave scars on the bone where they attach (Witmer, 1995). However, not all muscles are sufficiently large to produce muscle scars, or they may share similar or obscure attachment sites that can make them difficult to locate (Bryant and Seymour, 1990). For these ambiguous muscles, it may be possible to reconstruct soft tissues based on their presence/ absence and qualitative or relative positions using the extant phylogenetic bracket (EPB) approach (Witmer, 1995). However, this method cannot calculate how large the muscles may be in the extinct species, or accurately estimate other quantifiable aspects of their anatomy. Various methods may be used to constrain muscle sizes, e.g., using the bony margins of their attachments and their pathways relative to other muscles (Hutchinson et al., 2011; Allen et al., 2013; Lautenschlager 2013; Persons IV et al., 2013; Cuff and Rayfield, 2015). However, it becomes more difficult to estimate muscle boundaries when there is no outer limit on the size of the muscles. Using convex hulls (e.g., Basu et al., 2016) or non-uniform rational bsplines (NURBs) (e.g., Bates et al., 2009) it is possible to estimate muscle volumes, but doing so incurs additional uncertainties from assumptions of the volume reconstruction methods. Thus advances in the area of soft tissue reconstruction, especially quantitative methods that can also address uncertainties, are important.

Panthera atrox (Leidy, 1853), the "American lion," was a large felid that lived in North America during the Pleistocene epoch before going extinct at the end of the last ice age, approximately $11 \mathrm{ka}$. Panthera atrox was derived from a Beringian population of $P$. spelaea (cave lion) evolving around $337 \mathrm{ka}$ (Barnett et al., 2009), with both species splitting from $P$. leo around 1.89Ma (Barnett et al., 2016). P. atrox has gained much attention over the last few decades due to the size of some of the specimens, with body mass estimates from the largest specimens ranging from $350 \mathrm{~kg}-420 \mathrm{~kg}$ (Sorkin, 2008), making the species one of the largest felids ever to have lived. However, due to the limited number of articulated or associated specimens, reconstructions have been based on composite specimens.
Here we outline a simple method for virtually reconstructing entire postcrania from CT scans using a well-preserved Panthera atrox specimen. Using muscle scaling equations from Cuff et al. (2016a, 2016b) for extant felids, we were able to estimate muscle and tendon masses and lengths for the individual. Digital representations of actual muscles from an Asian lion were then scaled so that the dimensions of the locomotor musculature of the limbs and vertebral column were reconstructed and could be placed in the appropriate positions as determined from dissections of living relatives via the EPB method. We also check how well our muscled restorations match the results of different convex hull methods applied to regions of the body.

\section{METHODS}

Page Museum specimen LACMP23-555 is a remarkably well-preserved skull and postcranial skeleton of Panthera atrox from the La Brea Tar Pits (Project 23-1), dating to approximately $35 \mathrm{ka}$ (Fuller et al., 2014). The remains consist of a complete skull, complete limbs (minus manus and pes), girdles (although scapulae and pelvis are damaged), and a relatively complete vertebral column up to the caudal vertebrae (minus thoracic vertebrate T1, T5, T7, and T10). All of the bones were microCT scanned at The Aerospace Corporation (El Segundo, California, USA), with a GE Phoenix c/tome/x scanner (all scans $200 \mathrm{kV}, 80 \mathrm{~mA}$, voxel size $=0.24 \times 0.24 \times 0.24 \mathrm{~mm}$ ). For the reconstruction, primarily the bones of the left side and axial skeleton (Appendix 1 for complete list) were segmented from the scans in Mimics 16.0 software (Materialise NV, Leuven, Belgium), to export .stl files representing each bone. In the case of multiple scans for individual bones (the skull and all long bones), multiple .stl files were exported, which were then merged in Meshlab 1.3.3 software (Visual Computing Lab, ISTI - CNR, Pisa, Italy) using the "Align" function. Where bones from the right side were used, these were mirrored to the left side in Meshlab to produce a complete left side of the skeleton.

The missing thoracic vertebrae $\mathrm{T} 1, \mathrm{~T} 5$, and $\mathrm{T} 7$ were copied from the adjacent T2, T4, and T6 bones, respectively, as these were determined to be most similar in other felids (Randau et al., 2016). Vertebra number T10 is not present in the specimen, so this vertebra was replaced with the T10 of another specimen (LACMP 2458-19) of comparable size. The remainder of the bones from the left hand side (manus, pes, sternum, ribs, caudal vertebrae) were segmented from an Asian lion 
(Panthera leo persica) that had been scanned at the Royal Veterinary College using a Lightspeed Pro 16 CT scanner (GE Medical Systems) to obtain helical scans for the individual limbs and vertebral column $(120 \mathrm{kV}, 100 \mathrm{~mA}$; resolution of $0.96 \times 0.96 \times 1.25 \mathrm{~mm}$ ), and scaled isometrically from the $133 \mathrm{~kg}$ Asian lion to the estimated $207 \mathrm{~kg}$ body mass for this specimen of $P$. atrox (average from condylobasal length of $0.326 \mathrm{~m}$ (Mazák et al., 2011) and femoral length of $0.404 \mathrm{~m}$ - from the allcarnivoran equation (Anyonge, 1993), estimates of $195 \mathrm{~kg}$ and $219 \mathrm{~kg}$, respectively). These methods were chosen rather than using bone circumferences as it has been noted that $P$. atrox has relatively robust bones for their length (Sorkin 2008), and using the felid-specific equations from Anyonge (1993) lead to estimates of maximal $P$. atrox masses potentially exceeding $600 \mathrm{~kg}$. Recent works produce much lower maximal body mass estimates for $P$. atrox (Sorkin, $2008-420 \mathrm{~kg}$; Christiansen and Harris, $2009-351 \mathrm{~kg}$ ). Whilst there are issues with averaging two bivariate regressions (for an in depth discussion Smith, 2002 and references contained therein), we do not know which of the regressions is more reliable so we used the average of the two regressions as a guide. Those regressions' estimates of $195 \mathrm{~kg}$ and $219 \mathrm{~kg}$ body mass differ by about $12 \%$, which we viewed as plausibly close enough to warrant averaging them, given other potential sources of biological variation and methodological errors.

The finished .stl files for all of the bones were imported into Meshmixer 10.9.332 software (Autodesk, Inc.) where they were all manually aligned into a biologically plausible position based on the approximate standing posture of extant felids. The complete limbs were mirrored to create the right side and then aligned to the skeleton.

The Asian lion (National Museums of Scotland specimen NMS.Z.2015.128) was CT scanned with the muscles intact, and, despite having no contrast staining with Lugol's iodine (Kelly, 1961; Jeffery et al., 2011), we were able to segment all of the muscles from the left limbs (Figure 1). We were not able to segment the individual muscles of the vertebral column, so a gross segmentation of the cervical, thoracic, and lumbar regions of muscles was conducted. Using the scaling equations (inserting the $207 \mathrm{~kg}$ body mass estimate) from Cuff et al. (2016a, 2016b), the muscle belly length (i.e., length of the main striated muscle portion of the muscle-tendon unit, along its line of action) for each of the muscles was estimated for Panthera atrox. The expected muscle masses were also cal- culated from the Cuff et al. (2016a, 2016b) nonphylogenetic scaling equations (Appendices 2-13). The dataset from Cuff et al. (2016a, 2016b) has no large non-pantherine species and as such using the phylogenetic correction would likely reduce any real allometric signals; this could be particularly problematic due to $P$. atrox being a very large felid. Regardless, most muscle lengths and masses across the postcrania of felids scale (indistinguishable from) isometrically - whether or not phylogeny is accounted for - so the results are unlikely to differ greatly depending on which equation is chosen. The segmented muscles were individually scaled to match the predicted muscle length. Because the mass for each muscle and the corresponding .stl file was known from dissection of the $P$. leo specimen, and mass is proportional to volume (assuming density is the same for both muscles), after the length was scaled the two remaining dimensions were then scaled identically so the mass of each muscle matched that predicted from the scaling equations:

$$
\begin{gathered}
\text { Eq 1: } \text { Mass }_{\mathrm{P} . \text { atrox }}=\text { Mass }_{\mathrm{P} \text { leo }} \mathrm{x} \\
\text { length scale factor } \mathrm{x} \text { width scale factor }{ }^{2}
\end{gathered}
$$

This method was repeated for any tendons, where possible. However, the soft tissue contrast in the microCT scan images was often insufficient to separate tissues in the distal limbs, particularly for the long and relatively thin tendons. Thus most of the distal muscles lacked complete tendons in the resulting .stl files. For those distal muscles for which there were no easily segmented tendons, the tendons were recreated by extending a section of the muscle belly so that the length and mass of each tendon matched the mean lengths and masses expected from the scaling equations of Cuff et al. (2016a, 2016b). All of the scaled muscles and tendons were then placed on the left side of the $P$. atrox reconstructed skeleton in the appropriate positions using any evident muscle scarring patterns on the bones and the origins and insertions observed during dissections of extant species, before mirroring to the right side (as with the bones) in Meshlab.

We attempted to compare the body and segment mass estimates from convex hull models based on the reconstructions using just the skeleton and using the fully-fleshed model. This was done by using the "convex hull" filter within Meshlab for the skeletal elements from each of the body segments (e.g., Basu et al., 2016). Body mass estimates were calculated from the sum of all masses from the complete set of convex hulls using a 


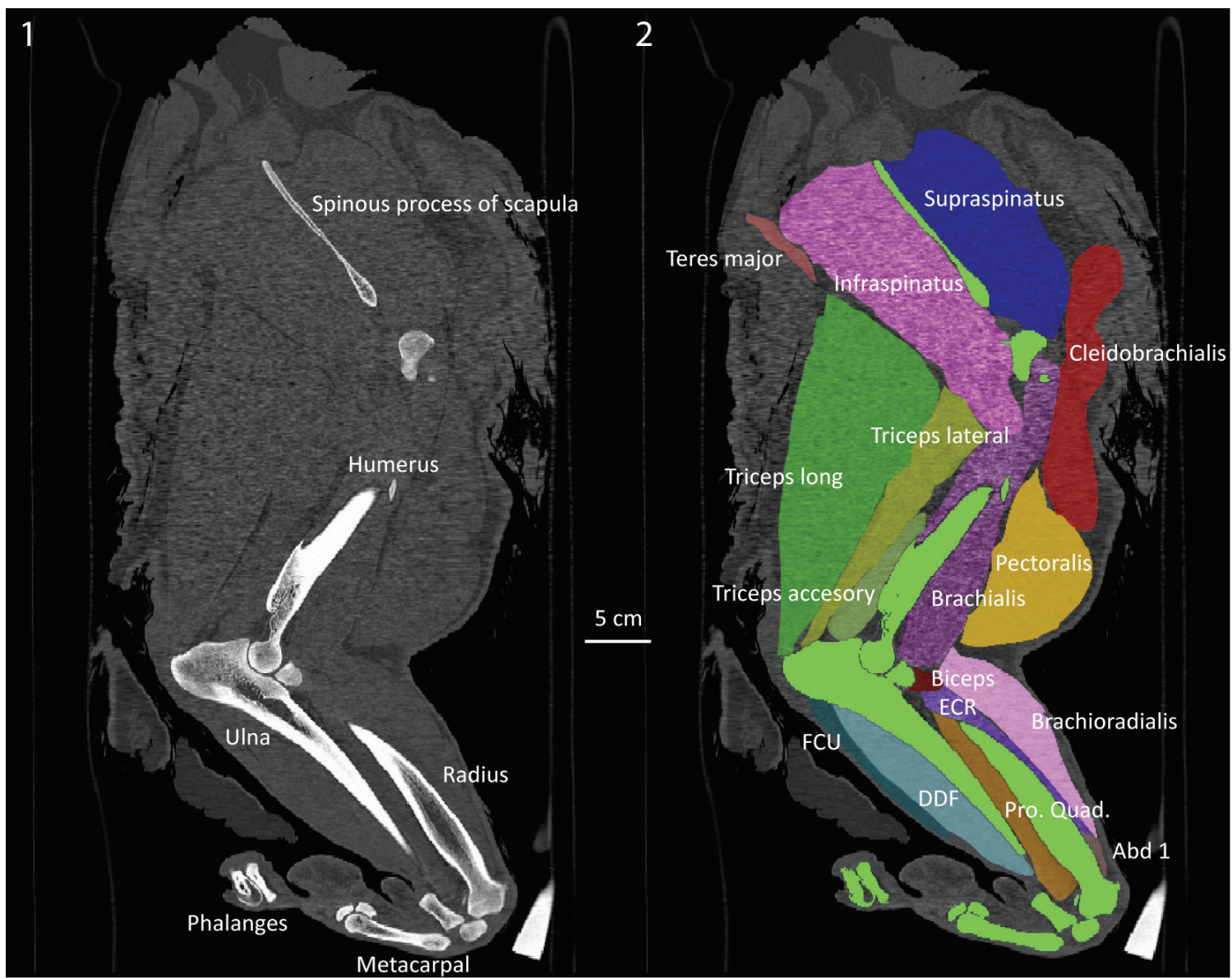

FIGURE 1. CT scan slice showing an approximately mediolateral view (i.e., longitudinal section) of an Asian lion's forelimb. 1, Dark grey is adipose and connective tissues, lighter grey is muscles, white is bone. Bottom right corner white is a density calibration phantom $\left(1.69 \mathrm{~g} \mathrm{~cm}^{-3}\right.$; "cortical bone"). 2, Segmentation of the lion forelimb with select muscles highlighted. Abbreviations: FCU - flexor carpi ulnaris; DDF - deep digital flexors; ECR - m. extensor carpi radialis; Pro Quad - m. pronator quadratus; Abd1 - m. abductor digiti I.

range of densities from $893.36 \mathrm{~kg} \mathrm{~m}^{-3}$ multiplied by 1.091 to 1.322 (i.e., $974.7 \mathrm{~kg} \mathrm{~m}^{-3}$ to $1181 \mathrm{~kg} \mathrm{~m}^{-3}$ a correction factor due to the underestimation of limb masses) (Sellers et al., 2012). In addition to total body mass estimations, convex hull estimates were made of the individual limb segments and compared to the values from the reconstructions. Finally estimations of segment masses were carried out using the same convex hull methods, but applied to the fully fleshed model for the limb segments rather than to the isolated bones. These data were validated by repeating the methods for a modern lion's left limbs, with the total volumes for each limb segment being isolated from CT scan data, and multiplied by a density of $1060 \mathrm{~kg} \mathrm{~m}^{-3}$.

\section{RESULTS AND DISCUSSION}

Although the resulting skeletal reconstruction was, necessarily, a composite using some elements from either another Panthera atrox individuals or the cadaver of $P$. leo, it is the most complete scientific reconstruction of a single $P$. atrox specimen to date (Figure 2). Combined with the skeletal reconstruction, dissections of related species, and recent analyses of felid muscle scaling, the muscles could be reconstructed (Tables 1-3) and placed onto the skeleton (Figure 3 ). As somewhat of a "best case" scenario for reconstructing an extinct animal's morphology, we used the musculature of a modern lion (phylogenetically the closest relative of $P$. atrox among extant felids, with less than $1.89 \mathrm{Ma}$ separating them) and scaled the muscles to the predicted size using the scaling 


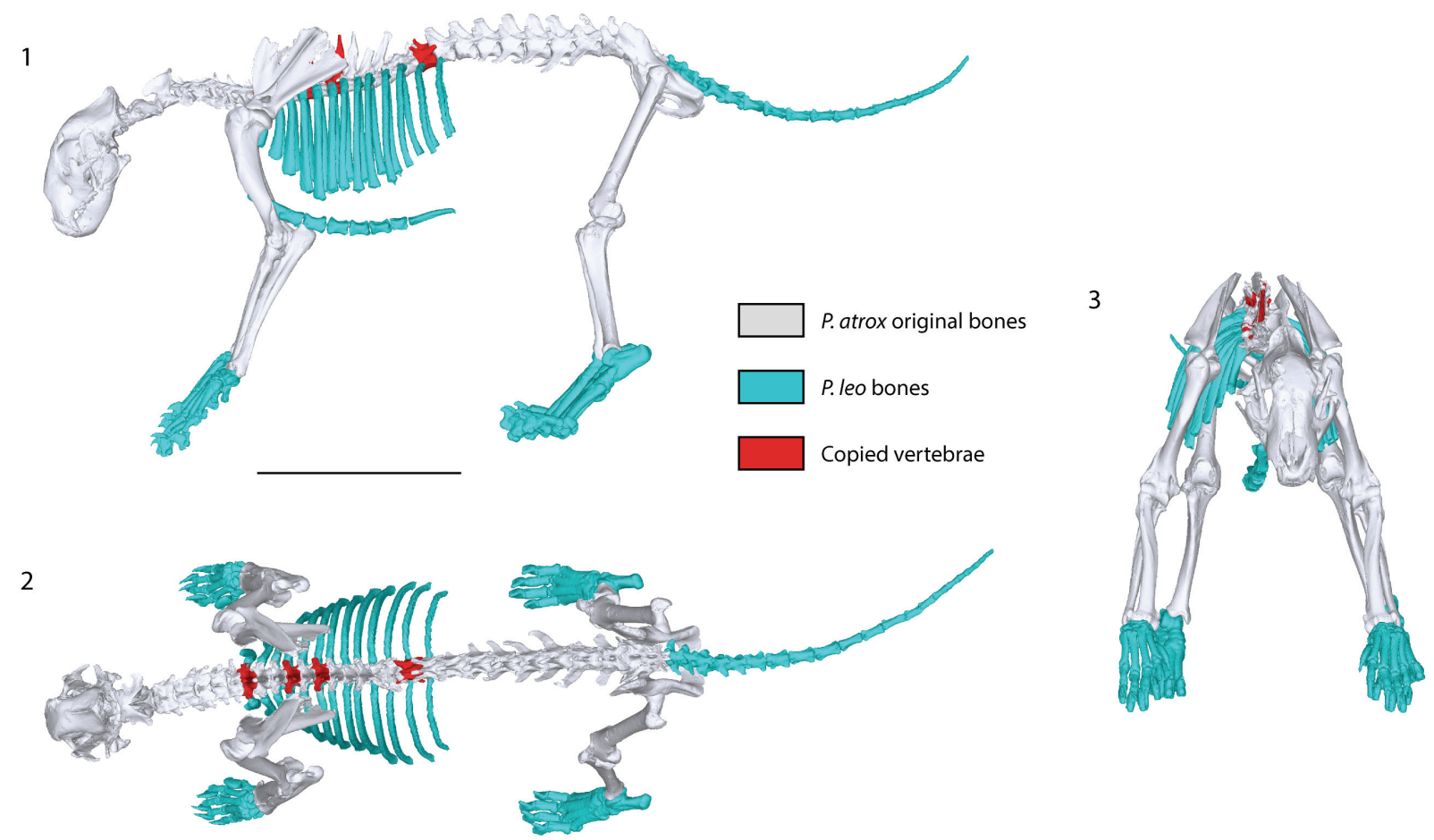

FIGURE 2. Skeletal reconstruction showing the original bones from Panthera atrox and those which have been copied from other vertebrae (red), or from P. leo persica (blue). 1, lateral; 2, dorsal; 3, anterior views. Scale bar is $50 \mathrm{~cm}$.

equations. These muscles, when scaled, generally matched the osteology very well (e.g., the scapular muscles of the $\mathrm{m}$. infraspinatus and $\mathrm{m}$. supraspinatus tightly bound by spinous process of the scapula, or the limb muscles closely wrapping the bones without intersecting each other or the bones). This good fit of the muscles to the skeleton might not be the case if the reconstructions were carried out on more distantly related taxa such as Smilodon, which is separated from all extant felids by $>20 \mathrm{Ma}$. Nonetheless, this whole-body reconstruction allowed presumably improved estimates of body segment dimensions (e.g., masses, centres of mass, moments of inertia) for this individual, and could also be applied to related species in the future.

The muscle reconstructions were derived in part from body mass, so they will be sensitive to which method is used to estimate body mass. The $207 \mathrm{~kg}$ body mass used here was derived from equations that give mass estimates from 195-219 $\mathrm{kg}$ - a range of $24 \mathrm{~kg}$ (around $12 \%$ of body mass). Using the two estimates for body mass, the calculated estimates for muscle and tendon length differed by around $4 \%$, and the muscle and tendon masses varied by around $12 \%$. However, the source of greater uncertainty in the muscle and tendon estimates was the scaling equations, which for some metrics had particularly large error margins (linked to the small number of individuals sampled by Cuff et al., 2016a, 2016b). For those muscles, unrealistic predictions may occur (Appendices $2-13$ for $95 \%$ confidence intervals for all muscles and tendons). Post hoc adjustments were made for those muscles by using the origin and insertion points to obtain lengths that matched the skeleton best. In particular, the $\mathrm{m}$. brachioradialis muscle's belly length was predicted to be $2.41 \mathrm{~m}$ long (Table 1), but from insertion and origination points was actually reconstructed at $0.275 \mathrm{~m}$ long, and the $\mathrm{m}$. rectus femoris tendon length was predicted to be $0.65 \mathrm{~m}$ long, but was reconstructed as $0.060 \mathrm{~m}$. This is also the case with some of the vertebral muscles (e.g., the estimated length of $\mathrm{m}$. semispinalis capitis biventer was almost double the length of the entire Panthera atrox skeletal reconstruction), but the individual vertebral muscles could not be individually segmented from the CT scans.

Our method developed here for whole-body reconstruction of Panthera atrox is based on the usage of scaling equations that relate bone dimensions and body mass, permitting estimation of the latter. These equations have been shown to be 
TABLE 1. Forelimb muscle belly and tendon lengths and masses as predicted from Cuff et al. (2016a). Serrat. vent. cerv. $=\mathrm{m}$. serratus ventralis cervicus, Serrat. vent. thor. $=\mathrm{m}$. serratus ventralis thoracis, Abd. dig. $1=\mathrm{m}$. abductor digiti 1. Ext. $=$ extensor, Flex. $=$ flexor.

\begin{tabular}{|c|c|c|c|c|}
\hline Muscle & $\begin{array}{l}\text { Belly length } \\
\text { (m) }\end{array}$ & $\begin{array}{l}\text { Tendon length } \\
(\mathrm{m})\end{array}$ & $\begin{array}{l}\text { Belly mass } \\
(\mathrm{kg})\end{array}$ & $\begin{array}{c}\text { Tendon mass } \\
(\mathbf{k g})\end{array}$ \\
\hline Latissimus dorsi & 0.646 & & 1.776 & \\
\hline Trapezius cervicis & 0.379 & & 0.229 & \\
\hline Trapezius thoracis & 0.275 & & 0.242 & \\
\hline Rhomboideus capitis & 0.428 & & 0.232 & \\
\hline Rhomboideus cervicis & 0.230 & & 0.444 & \\
\hline Rhomboideus thoracis & 0.204 & & 0.156 & \\
\hline Omotransversarius & 0.350 & & 0.169 & \\
\hline Cleidocephalicus & 0.405 & & 0.484 & \\
\hline Cleidobrachialis & 0.336 & 0.140 & 0.509 & \\
\hline Serrat. vent. cerv. & 0.244 & & 0.523 & \\
\hline Serrat. vent. thor. & 0.240 & & 0.552 & \\
\hline Pectoralis superficialis & 0.372 & & 0.567 & \\
\hline Pectoralis profundus & 0.642 & & 1.923 & \\
\hline Supraspinatus & 0.344 & 0.045 & 1.001 & 0.001 \\
\hline Infraspinatus & 0.261 & 0.203 & 0.699 & 0.038 \\
\hline Deltoideus acromion & 0.184 & & 0.162 & \\
\hline Deltoideus spinous & 0.195 & 0.113 & 0.190 & 0.000 \\
\hline Teres major & 0.286 & 0.002 & 0.554 & 0.001 \\
\hline Subscapularis & 0.254 & 0.022 & 0.670 & 1.000 \\
\hline Teres minor & 0.091 & & 0.035 & \\
\hline Coracobrachialis & 0.644 & & 0.133 & \\
\hline Triceps longus & 0.348 & 0.130 & 1.562 & 0.006 \\
\hline Triceps lateralis & 0.277 & 0.101 & 0.582 & 0.005 \\
\hline Triceps medius & 0.253 & 0.136 & 0.197 & 0.010 \\
\hline Triceps accessory & 0.281 & & 0.123 & \\
\hline Biceps brachi & 0.257 & 0.102 & 0.531 & 0.012 \\
\hline Brachialis & 0.297 & 0.059 & 0.138 & 0.003 \\
\hline Anconeus & 0.165 & & 0.072 & \\
\hline Ext. carpi radialis & 0.310 & 0.163 & 0.201 & 0.008 \\
\hline Ext. digitorum communis & 0.236 & 0.014 & 0.186 & 0.074 \\
\hline Ext. digitorum lateralis & 0.415 & 0.169 & 0.054 & 0.008 \\
\hline Ext. carpi ulnaris & 0.264 & 0.163 & 0.077 & 0.005 \\
\hline Flex. carpi ulnaris ulnar & 0.262 & 0.021 & 0.139 & 0.003 \\
\hline Flex. carpi ulnaris humeral & 0.295 & 0.108 & 0.162 & 0.002 \\
\hline Brachioradialis & 2.410 & & 0.218 & \\
\hline Supinator & 0.147 & 0.002 & 0.039 & 0.004 \\
\hline Pronator teres & 0.216 & & 0.128 & \\
\hline Pronator quadratus & 0.254 & 0.073 & 0.071 & 0.004 \\
\hline Flex. carpi radialis & 0.259 & 0.081 & 0.058 & 0.002 \\
\hline Flex. digitorum complex & 0.284 & 0.177 & 0.499 & 0.087 \\
\hline Abd. dig. 1 & 0.418 & 0.223 & 0.039 & 0.003 \\
\hline
\end{tabular}


TABLE 2. Hindlimb muscle belly and tendon lengths and masses as predicted from Cuff et al. (2016b). Gastroc. = gastrocnemius, Dig. = digitorum, Supefic. $=$ superficialis.

\begin{tabular}{|c|c|c|c|c|}
\hline Muscle & $\begin{array}{l}\text { Belly length } \\
\text { (m) }\end{array}$ & $\begin{array}{l}\text { Tendon length } \\
(\mathrm{m})\end{array}$ & $\begin{array}{l}\text { Belly mass } \\
(\mathrm{kg})\end{array}$ & $\begin{array}{c}\text { Tendon mass } \\
(\mathbf{k g})\end{array}$ \\
\hline Biceps femoris & 0.420 & & 1.537 & \\
\hline Caudofemoralis & 0.373 & 0.345 & 0.515 & 0.019 \\
\hline Sartorius & 0.654 & & 0.775 & \\
\hline Tensor fascia latae & 0.190 & 0.293 & 0.542 & 0.043 \\
\hline Vastus lateralis & 0.389 & & 0.962 & \\
\hline Rectus femoris & 0.419 & 0.650 & 0.693 & 0.079 \\
\hline Vastus medius & 0.350 & 0.029 & 0.487 & 0.004 \\
\hline Vastus intermedius & 0.486 & 0.002 & 0.168 & 0.000 \\
\hline Semitendinosus & 0.464 & 0.134 & 0.684 & 0.005 \\
\hline Semimembranosus & 0.718 & 0.043 & 1.369 & 0.003 \\
\hline Gracilis & 0.257 & 0.088 & 0.534 & 0.016 \\
\hline Gluteus superficialis & 0.184 & & 0.153 & \\
\hline Gluteus medius & 0.249 & & 1.063 & \\
\hline Gluteus profundus & 0.231 & 0.005 & 0.090 & 0.001 \\
\hline Piriformis & 0.090 & 0.023 & 0.093 & 0.002 \\
\hline Gemelli & 0.154 & & 0.146 & \\
\hline Quadratus femoris & 0.125 & & 0.046 & \\
\hline Obturator externus & 0.124 & & 0.168 & \\
\hline Obturator internus & 0.118 & 0.078 & 0.178 & 0.008 \\
\hline Pectineus & 0.268 & & 0.093 & \\
\hline Adductor magnus & 0.392 & & 1.181 & \\
\hline Adductor brevis & 0.214 & & 0.211 & \\
\hline Iliacus & 0.564 & & 0.538 & \\
\hline Psoas major & 0.558 & 0.058 & 0.785 & 0.074 \\
\hline Psoas minor & 0.373 & 0.072 & 0.242 & 0.002 \\
\hline Gastroc. lateralis & 0.334 & 0.072 & 0.377 & 0.021 \\
\hline Gastroc. medius & 0.291 & 0.137 & 0.302 & 0.021 \\
\hline Superfic. dig. flexor & 0.293 & 0.373 & 0.119 & 0.311 \\
\hline Soleus & 0.268 & 0.024 & 0.123 & 0.002 \\
\hline Dig. extensor longus & 0.291 & 0.269 & 0.084 & 0.105 \\
\hline Tibialis cranialis & 0.284 & 0.111 & 0.213 & 0.004 \\
\hline Popliteus & 0.189 & 0.095 & 0.054 & 0.003 \\
\hline Dig. extensor lateralis & 0.215 & 0.320 & 0.026 & 0.003 \\
\hline Peroneus longus & 0.222 & 0.166 & 0.185 & 0.062 \\
\hline Peroneus brevis & 0.200 & 0.242 & 0.041 & 0.004 \\
\hline Deep digital flexor medial & 0.298 & 0.299 & 0.165 & 0.062 \\
\hline Deep digital flexor lateral & 0.324 & 0.465 & 0.137 & 0.040 \\
\hline Tibialis caudalis & 0.272 & 0.180 & 0.117 & 0.011 \\
\hline
\end{tabular}


TABLE 3. Vertebral muscle belly and tendon lengths and masses as predicted from Cuff et al. (2016a, b). Longis. = longissimus, lliocost. $=$ iliocostalis, Multifid. $=$ multifidus.

\begin{tabular}{|c|c|c|c|c|}
\hline Muscle & $\begin{array}{l}\text { Belly length } \\
\text { (m) }\end{array}$ & $\begin{array}{l}\text { Tendon length } \\
\text { (m) }\end{array}$ & $\begin{array}{l}\text { Belly mass } \\
(\mathbf{k g})\end{array}$ & $\begin{array}{c}\text { Tendon mass } \\
(\mathbf{k g})\end{array}$ \\
\hline Rectus capitis & 0.112 & & 0.098 & \\
\hline Splenius cervicis & 0.395 & & 0.366 & \\
\hline Serratus dorsalis cranialis & 0.127 & 0.228 & 0.124 & 0.033 \\
\hline Serratus dorsalis caudalis & 0.085 & 0.001 & 0.080 & 0.020 \\
\hline Semispinalis capitis biventer & 4.009 & & 0.325 & \\
\hline Semispinalis capitis complexus & 0.470 & & 0.325 & \\
\hline Spinalis cervicis & 0.314 & & 0.336 & \\
\hline Spinalis thoracis & 0.641 & & 0.877 & \\
\hline Longissimus capitis & 0.323 & & 0.064 & \\
\hline Longissimus cervicis & 0.405 & & 0.143 & \\
\hline Longissimus thoracis & 0.827 & & 0.916 & \\
\hline Iliocostalis thoracis & 0.640 & & 0.195 & \\
\hline Multifidis throacis & 0.713 & & 0.355 & \\
\hline Longis. lumborum & 2.342 & & 0.987 & \\
\hline Iliocost. lumborum & 1.494 & & 0.630 & \\
\hline Multifid. lumborum & 0.381 & & 0.661 & \\
\hline
\end{tabular}

very good $\left(r^{2}>0.95\right)$ at estimating body masses for extant Panthera species (Anyonge, 1993; Mazák et al., 2011) and by using them we also produced a reasonable estimation for body composition (Table 4) compared to modern P. leo. The musculature of extant lions accounts for (on average) $57.1 \%$ of total body mass, then the remainder of body mass is $11.5 \%$ skin, $12.4 \%$ skeleton, $11.8 \%$ organs, about $4.6 \%$ blood and waste, and $2.7 \%$ fat (Davis, 1962). For $P$. atrox, the muscles and their respective tendons reconstructed from the scaling equations of Cuff et al. (2016a, 2016b) correspond to $84.4 \mathrm{~kg}$ in mass $(40.8 \%$ of total body mass calculated from the bone regression). Of course, other muscles (e.g., abdominal, intercostal, hyomandibular, and various intrinsic muscles of the manus, pes, and skull) would add to the muscle mass further. However, it would be surprising if there was another $16.3 \%$ of body mass in this remaining musculature as this musculature only corresponds to approximately $2-3 \%$ of total mass in domestic cats (Grand, 1977). This discrepancy may be due to the different methods of preparation between Cuff et al. (2016a, 2016b), where individual muscles were dissected, and Davis (1962), which does not appear to have removed extraneous connective tissues and intermuscular adipose tissues. This suggestion is somewhat supported by the relatively low body fat content of lions $(2.7 \%)$ esti- mated by Davis (1962), relative to those reported for other felid species for which data are available (domestic cat: $20.9 \%$ (Lauten et al., 2000) - 24.4\% (Munday et al., 1994); Lynx spp. $15-16 \%$ (Pitts and Bullard, 1968)).

Convex hull models have been used recently to reconstruct body segmental shapes and estimate body masses for skeletons with no preserved soft tissues (e.g., Sellers et al., 2012; Basu et al., 2016; Bates et al., 2016; Brassey et al., 2016). The convex hull model for the entire skeleton of $P$. atrox produced a volume of $0.185 \mathrm{~m}^{3}$ (Figure 4). Using the range of potential densities (Sellers et al., 2012), the body mass estimates varied from $180 \mathrm{~kg}$ to $219 \mathrm{~kg}$. The mid-point of these two extreme ranges is $200 \mathrm{~kg}$, only a few kilograms away from the $\sim 207 \mathrm{~kg}$ estimate obtained from the bones, which is unsurprising as the composite bones were scaled to the $207 \mathrm{~kg}$ estimate. However, as convex hulls tend to underestimate total volumes, methods for estimating masses from them are heavily reliant on the density values used (e.g., a density of 1359 $\mathrm{kg} \mathrm{m}^{-3}$ from Brassey and Sellers (2014), which they calculated to be the apparent density for convex hull models for non-primate mammals, would produce a very different estimate of $251 \mathrm{~kg}$ for the uncorrected convex hull of this Panthera atrox specimen). Whilst convex hull models can produce realistic estimates for total mass, they will produce 


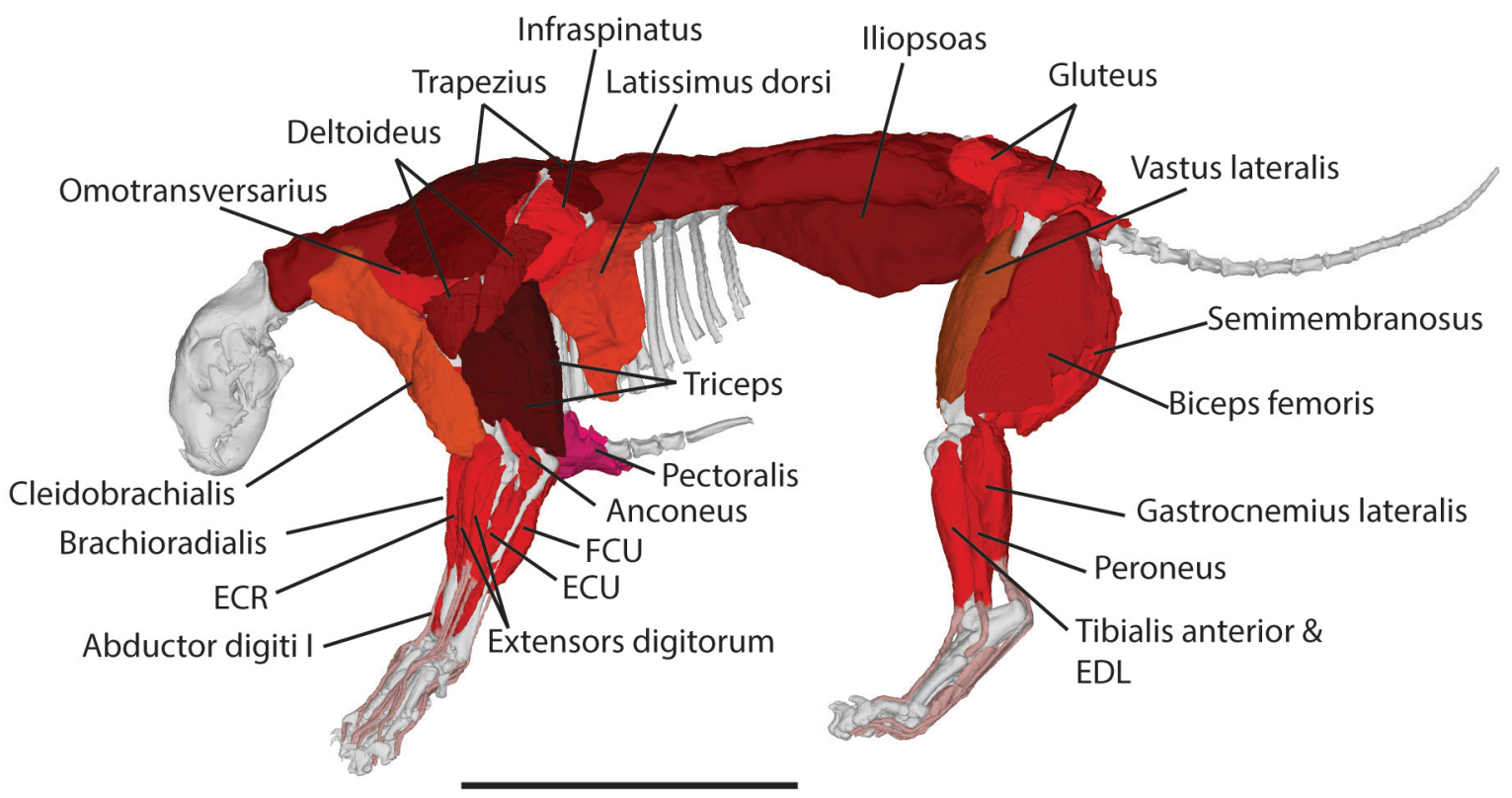

FIGURE 3. Muscled reconstruction of Panthera atrox showing the major muscle groups in lateral view. Abbreviations: FCU - m. flexor carpi ulnaris; ECU - m. extensor carpi ulnaris; ECR - m. extensor carpi radialis; EDL - m. extensor digitorum longus. Scale bar is $50 \mathrm{~cm}$.

regional variability, with the limb masses generally underestimated, and the core body overestimated (Sellers et al., 2012; Brassey and Sellers, 2014). The muscled reconstruction of $P$. atrox showed how much variability was obtained for the limb morphology (Figure 5).

On the modern lion, convex hull-based models of the bones produced segmental estimates that were up to 3.7 times and 5.23 times smaller than the masses of the muscles and bones in the proximal sections of the fore- and hindlimbs, respectively (Table 5). However, using reconstructed muscles and bones together still underestimated total limb mass by a factor of 1.3-1.8 (Table 5 ) due to the lack of connective tissues, blood vessels, nerves, adipose tissue, and skin. This discrepancy could be compensated for by producing a convex hull model of the limb over the muscled reconstructions, which produced mass estimates that were within $8 \%$ of the actual fleshed limb segments (Table 5), rather than producing the original $\sim 30-80 \%$ underestimates.

For any biomechanical model of a species it is important to understand more than just the masses of the segments, but also the segmental centres of mass and moments of inertia, all of which determine how the segments might have moved (Allen et al., 2009, 2013). The convex hull models of the muscled limb segments for Panthera leo produced centre of mass (COM) estimates that were very close to those from CT scan segmentation in terms of absolute distances, and percentages of segment length (Table 6), suggesting this method of recon-

TABLE 4. Body composition of Panthera atrox from reconstructed muscles and dissections of extant $P$. leo specimens (Davis, 1962). "Muscle recon" is the sum of the reconstructed forelimb, hindlimb, and vertebral muscles. Additional muscle is the remaining expected muscle using the body compositions for modern lions (Davis, 1962) i.e., 57.1\% "Muscle recon".

\begin{tabular}{|c|c|c|c|c|c|c|c|c|c|c|c|}
\hline & Body & $\begin{array}{l}\text { Forelimb } \\
\text { muscles }\end{array}$ & $\begin{array}{l}\text { Hindlimb } \\
\text { muscles }\end{array}$ & $\begin{array}{c}\text { Vertebral } \\
\text { muscle }\end{array}$ & $\begin{array}{c}\text { Muscle } \\
\text { recon }\end{array}$ & $\begin{array}{c}\text { Additional } \\
\text { muscle }\end{array}$ & Bone & Adipose & Organs & Skin and fur & $\begin{array}{c}\text { Blood } \\
\text { and } \\
\text { waste }\end{array}$ \\
\hline Mass $(\mathrm{kg})$ & 207 & 35.2 & 32.2 & 16.9 & 84.4 & 33.7 & 25.7 & 5.5 & 24.4 & 23.8 & 9.56 \\
\hline $\begin{array}{l}\text { Percentage } \\
(\%)\end{array}$ & 100 & 17.0 & 15.6 & 8.18 & 40.8 & 16.3 & 12.4 & 2.67 & 11.8 & 11.5 & 4.62 \\
\hline
\end{tabular}




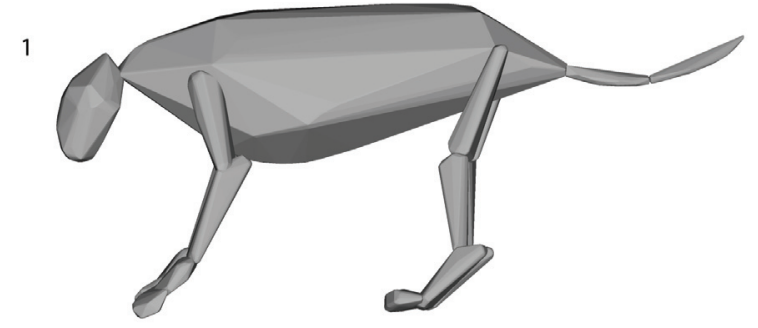

2

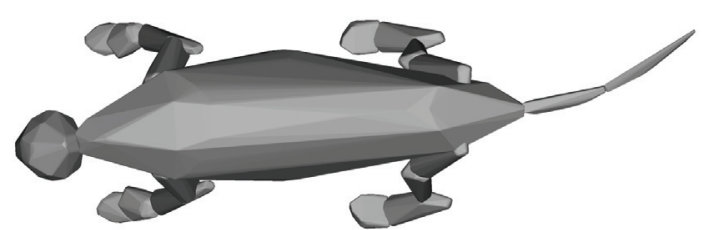

FIGURE 4. Convex hull model from the reconstructed Panthera atrox skeleton shown in Figure 2. 1, left lateral view; 2, dorsal view. Scale bar is $50 \mathrm{~cm}$. structing limb segments is comparable to the original fleshed limb.

From our reconstructions of the limb segments for Panthera atrox, the mass estimates from the convex hulls over the bones relative to the muscle and bone masses are comparable to those of $P$. leo (Tables 5 and 7 ). This result supports the conclusion that the convex hulls over the reconstructed muscles will also be similarly accurate for $P$. atrox as they were for $P$. leo. For the hindlimbs, the percentage of the total mass for each segment was very similar to those of domestic cats, but the forelimb segments in $P$. atrox were almost double the typical mass measured in domestic cats (Grand, 1977). As the muscle masses appear to scale isometrically in the forelimbs of felids (Cuff et al., 2016a) and there is only a few percentage points difference (in terms of total body mass) between the forelimb muscles of $P$. atrox and domestic cats, this increase in mass is probably

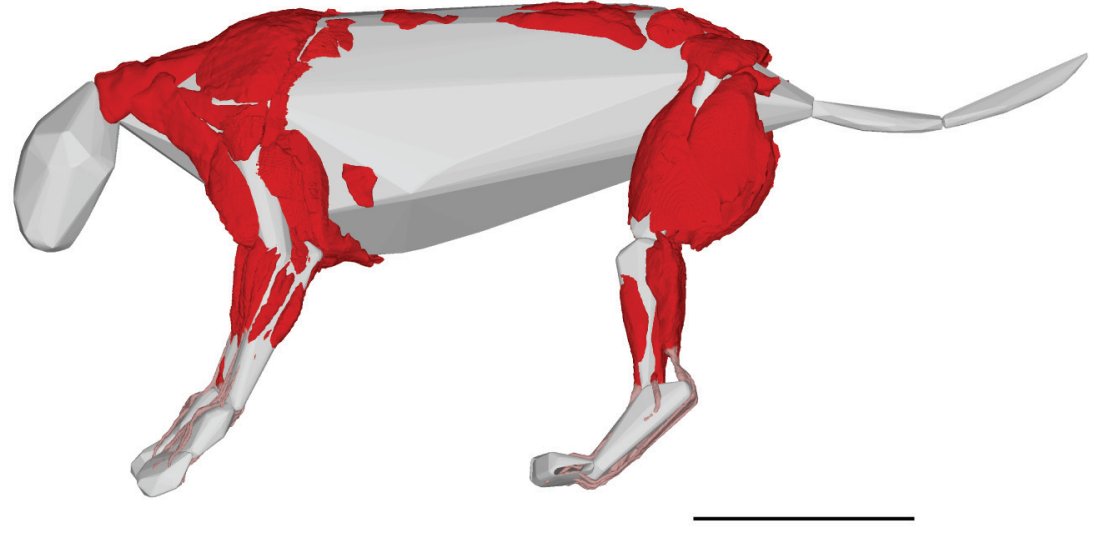

2

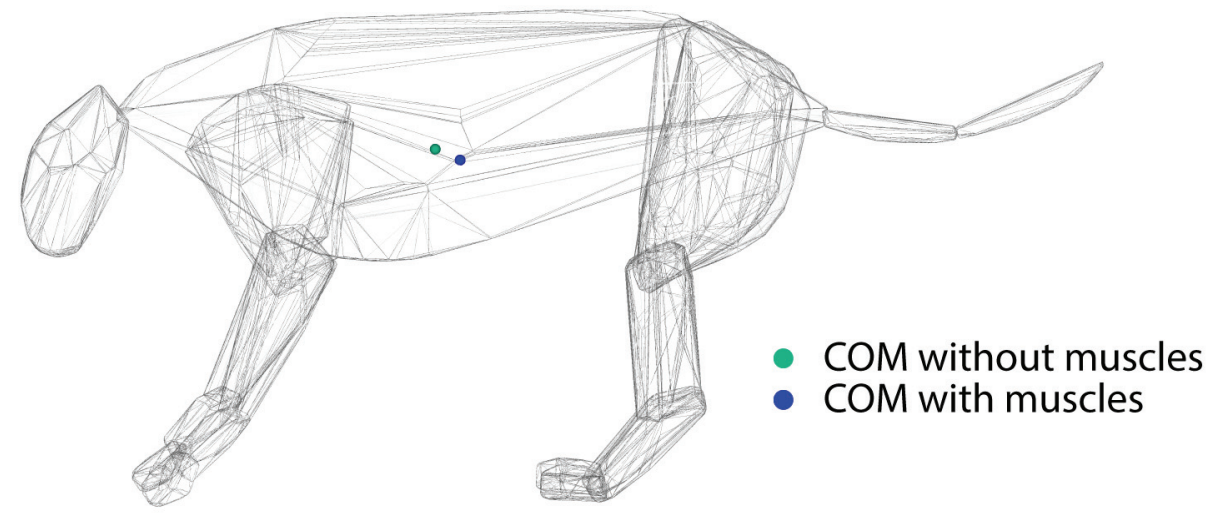

FIGURE 5. Panthera atrox reconstruction showing differences between simple convex hulls and more complex reconstructions. 1, Reconstructed muscles overlaid on the convex hull of just the bones. Any muscles that are visible extend beyond the range of the convex hull, thereby demonstrating the underestimation of size by convex hulls based solely on bones. 2, Reconstructions showing the posteroventral movement of the centre of mass (COM) between the bone convex hull and the muscled convex hull models of Panthera atrox. Scale bar is $50 \mathrm{~cm}$. 
TABLE 5. Panthera leo limb segment masses from the different mass estimate methods. "Flesh" is the weight calculated for the segment volumes (multiplied by $1060 \mathrm{~kg} \mathrm{~m}^{-3}$ ) from CT segmentation. "Reconstruction" was based on the muscle and bone reconstruction, although muscle masses for the manus and pes were calculated as total tendon mass for distal muscles. Convex hull bones ("CHB") is the convex hull range of masses and the convex hull muscles ("CHM") is the convex hull range of masses from the muscled reconstructions. The masses for both convex hull methods were calculated from the volumes using only the mean density [893.36 $\mathrm{kg} \mathrm{m}^{-3}$ multiplied by 1.206 (Sellers et al., 2012)]. Ratios of each of these estimates are shown in the final four columns on the right side of the table. Dig_Man = digits of the manus, Dig_Pes = digits of the pes.

\begin{tabular}{|c|c|c|c|c|c|c|c|c|c|c|}
\hline & \multirow[b]{2}{*}{ Flesh } & \multicolumn{3}{|c|}{ Reconstruction } & \multirow{2}{*}{$\begin{array}{l}\text { CHB } \\
\text { Mean }\end{array}$} & \multirow{2}{*}{$\begin{array}{l}\text { CHM } \\
\text { Mean }\end{array}$} & \multirow{2}{*}{$\begin{array}{l}\text { Flesh/ } \\
\text { Recon }\end{array}$} & \multirow{2}{*}{$\begin{array}{c}\text { Recon/ } \\
\text { CHB }\end{array}$} & \multirow{2}{*}{$\begin{array}{l}\text { CHM/ } \\
\text { Recon }\end{array}$} & \multirow{2}{*}{$\begin{array}{c}\text { Flesh/ } \\
\text { CHM }\end{array}$} \\
\hline & & Bone mass & Muscle mass & Total & & & & & & \\
\hline Humerus & 7.47 & 0.44 & 3.94 & 4.38 & 1.19 & 7.29 & 1.71 & 3.69 & 1.67 & 1.02 \\
\hline Ulna/Radius & 2.39 & 0.16 & 1.40 & 1.56 & 0.86 & 2.25 & 1.53 & 1.81 & 1.44 & 1.07 \\
\hline Manus & 0.55 & 0.18 & 0.29 & 0.47 & 0.42 & & 1.18 & 1.12 & & \\
\hline Dig_Man & 0.44 & 0.07 & & 0.07 & 0.29 & & 6.16 & 0.24 & & \\
\hline Femur & 10.9 & 0.62 & 7.23 & 7.85 & 1.50 & 10.6 & 1.39 & 5.23 & 1.35 & 1.03 \\
\hline Tibia & 2.35 & 0.53 & 1.13 & 1.66 & 1.28 & 2.54 & 1.41 & 1.30 & 1.53 & 0.92 \\
\hline Pes & 0.75 & 0.41 & 0.27 & 0.68 & 0.73 & & 1.10 & 0.93 & & \\
\hline Dig_Pes & 0.30 & 0.13 & & 0.13 & 0.29 & & 2.31 & 0.45 & & \\
\hline
\end{tabular}

TABLE 6. Centre of mass (COM) validation test for extant lion limb segments. "Original COM" was derived from CT scan data for each segment, "CHM COM" from the convex hull models fitted to the muscled limbs, and "Difference" is the "Original COM" minus "CHM COM". Italicised numbers are long axis lengths from which the percentage (\%) of segment lengths were calculated. Positive $x, y$, and $z$ are anterior, dorsal, and medial, respectively, relative to the origin at the proximal end of the segment. Centre of mass (COM) was expressed as \% of length (from the proximal end) relative to the total proximodistal length of the segment.

\begin{tabular}{|c|c|c|c|c|c|c|c|c|c|c|c|}
\hline & \multicolumn{3}{|c|}{ Original COM } & \multicolumn{3}{|c|}{ СHM СОМ } & \multicolumn{3}{|c|}{ Difference } & \multirow{2}{*}{$\begin{array}{c}\text { Original } \\
\% \text { of } \\
\text { length }\end{array}$} & \multirow{2}{*}{$\begin{array}{c}\text { CHM \% } \\
\text { of } \\
\text { length }\end{array}$} \\
\hline & $\mathbf{x}$ & $y$ & $\mathbf{z}$ & $\mathbf{x}$ & $y$ & $\mathbf{z}$ & $\mathbf{x}$ & $y$ & $\mathbf{z}$ & & \\
\hline Humerus & 0.0003 & -0.1120 & 0.005226 & -0.0067 & -0.1223 & 0.011691 & 0.0070 & 0.0103 & -0.0065 & 45.6 & 49.8 \\
\hline Ulna/Radius & -0.0023 & -0.1093 & 0.001969 & 0.0016 & -0.0935 & 0.002054 & -0.0038 & -0.0158 & -0.0001 & 42.7 & 36.6 \\
\hline Femur & -0.0201 & -0.0943 & -0.0177 & -0.0164 & -0.1098 & -0.0216 & -0.0037 & 0.0154 & 0.0039 & 32.1 & 37.4 \\
\hline Tibia & -0.0219 & -0.1497 & -0.0004 & -0.0230 & -0.1607 & -0.0009 & 0.0011 & 0.0111 & 0.0005 & 50.3 & 54.0 \\
\hline
\end{tabular}

linked to an increase in robustness of the bones (Sorkin, 2008; Doube et al., 2009) and may be correlated with the importance of the forelimbs to tackle prey in larger felids (Meachen-Samuels and Van Valkenburgh, 2009). Considering the close concordance of centres of mass between the segmental convex hull reconstructions of $P$. leo and its CT scan segmentation (Table 6), we can confidently reconstruct the limb segment COMs of $P$. atrox (Table 8), as well as the moments of inertia (Table 9). Additionally, we seemed to be able to more accurately estimate whole body COM, which is more posteroventrally located $(5.2 \mathrm{~cm}$ posteriorly, $3.1 \mathrm{~cm}$ ventrally) in the muscled convex hull models than in models using just the skeleton (Figure 5). By using empirical data from extant lions and other felids to reconstruct the muscles (and thus body segments) quantitatively, we were better able to reconstruct this fossil taxon in detail that was previously unobtainable.

\section{CONCLUSIONS}

Our microCT scan data from one very complete skeletal specimen enabled a new reconstruction of Panthera atrox in more complete detail than before, although where there were incomplete data we had to use portions of closely related taxa, and thus our reconstruction is still a composite. Using data derived from dissections of extant felids spanning a range of body masses, it was possible to use regressions to estimate the size of the locomotor musculature of this specimen of $P$. atrox. These reconstructions allowed for more accurate esti- 
TABLE 7. Reconstructed and convex hull masses for various segments of the body of Panthera atrox. Bone mass was calculated from estimated bone density $\left(1150 \mathrm{~kg} \mathrm{~m}^{-3}\right)$ based on relative bone mass (25.7 $\mathrm{kg}$ - Table 4) divided by total bone volume $\left(0.0223 \mathrm{~m}^{3}\right)$. Muscle mass was calculated from the muscle and tendon that forms the majority of the segment (e.g., M. biceps brachii has tendons that extend to the scapula and the ulna, but these are all counted to the mass of the humeral segment as that is the majority of the muscle and tendon) (Tables 1-3), with tendons for the distal muscles being placed in the manus and pes segments. Convex hull bones' (CHB) and convex hull muscles' (CHB) masses were calculated from the volumes multiplied by relative density $\left(893.36 \mathrm{~kg} \mathrm{~m}^{-3}\right.$ multiplied by $1.091,1.206$, and 1.322 (Sellers et al., 2012) respectively). Dig_Man and Dig_Pes are the digits for the manus and pes, respectively. The Recon/CHB is the ratio of reconstructed mass to $\mathrm{CHB}$ mass, and CHM/Recon is the ratio of the CHM mass to the reconstructed mass. Rad = radius, Dig_Man = digits of the manus, Fib = fibula, Dig_Pes = digits of the pes.

\begin{tabular}{|c|c|c|c|c|c|c|c|c|c|c|c|}
\hline & \multicolumn{3}{|c|}{ Reconstruction } & \multicolumn{3}{|c|}{ Convex Hull Bones } & \multicolumn{3}{|c|}{ Convex Hull Muscles } & \multirow[b]{2}{*}{ Recon/CHB } & \multirow[b]{2}{*}{ CHM/Recon } \\
\hline & Bone Mass & Muscle Mass & Total & Mean & Lower & Upper & Mean & Lower & Upper & & \\
\hline Humerus & 1.03 & 7.65 & 8.88 & 2.88 & 2.60 & 3.15 & 10.16 & 9.19 & 11.14 & 3.02 & 1.17 \\
\hline Ulna/Rad & 0.73 & 1.94 & 2.67 & 2.03 & 1.83 & 2.22 & 4.44 & 4.02 & 4.87 & 1.32 & 1.66 \\
\hline Manus & 0.34 & 0.20 & 0.54 & 0.92 & 0.84 & 1.01 & 1.28 & 1.16 & 1.40 & 0.59 & 2.35 \\
\hline Dig_Man & 0.17 & & 0.17 & 0.60 & 0.55 & 0.66 & 0.70 & 0.63 & 0.76 & 0.28 & 4.12 \\
\hline Femur & 1.12 & 13.5 & 14.63 & 2.90 & 2.62 & 3.18 & 17.60 & 15.92 & 19.29 & 5.05 & 1.20 \\
\hline Tibia/Fib & 0.87 & 1.99 & 2.86 & 1.89 & 1.71 & 2.07 & 4.33 & 3.92 & 4.75 & 1.51 & 1.52 \\
\hline Pes & 0.90 & 0.61 & 1.50 & 1.60 & 1.45 & 1.76 & 2.16 & 1.96 & 2.37 & 0.94 & 1.44 \\
\hline Dig_Pes & 0.28 & & 0.28 & 0.68 & 0.62 & 0.75 & 0.92 & 0.83 & 1.01 & 0.41 & 3.27 \\
\hline
\end{tabular}

TABLE 8. Centre of mass for Panthera atrox limb segments. Positive $x, y$, and $z$ are anterior, dorsal, and medial, respectively, relative to the origin at the proximal end of the segment. Centre of mass (COM) was expressed as \% of length (from the proximal end) relative to the total proximodistal length of the segment.

\begin{tabular}{lcccc}
\hline Segment & $\mathbf{x}$ & $\mathbf{y}$ & $\mathbf{z}$ & $\begin{array}{c}\text { COM \% } \\
\text { of length }\end{array}$ \\
\hline Humerus & 0.002 & -0.119 & 0.009 & 0.372 \\
Ulna & -0.002 & -0.117 & 0.001 & 0.360 \\
Manus & -0.010 & -0.118 & -0.001 & 0.622 \\
Digits & -0.015 & -0.045 & -0.009 & 0.414 \\
Femur & -0.012 & -0.144 & -0.018 & 0.380 \\
Tibia & -0.017 & -0.200 & -0.014 & 0.537 \\
Pes & -0.020 & -0.114 & -0.010 & 0.464 \\
Digits & 0.001 & -0.045 & -0.017 & 0.370 \\
\hline
\end{tabular}

TABLE 9. Moments of inertia (relative to the centre of mass; Table 8) for the limb segments of Panthera atrox. Units are $\mathrm{kg} \mathrm{m}^{2}$.

\begin{tabular}{|c|c|c|c|c|c|c|c|c|c|c|c|}
\hline \multicolumn{3}{|c|}{ Humerus } & \multicolumn{3}{|c|}{ Ulna } & \multicolumn{3}{|c|}{ Manus } & \multicolumn{3}{|c|}{ Digits } \\
\hline$x$ & $y$ & $z$ & $x$ & $\mathbf{Y}$ & $z$ & $x$ & $y$ & $\mathbf{z}$ & $\mathbf{x}$ & $y$ & $\mathbf{z}$ \\
\hline 0.1068 & 0.0616 & 0.1476 & 0.0551 & 0.0081 & 0.0576 & 0.0040 & 0.0015 & 0.0034 & 0.0012 & 0.0007 & 0.0010 \\
\hline \multicolumn{3}{|c|}{ Femur } & \multicolumn{3}{|c|}{ Tibia } & \multicolumn{3}{|c|}{ Pes } & \multicolumn{3}{|c|}{ Digits } \\
\hline$x$ & $y$ & $z$ & $x$ & $\mathbf{Y}$ & $z$ & $x$ & $y$ & $z$ & $\mathbf{x}$ & $y$ & $\mathbf{z}$ \\
\hline 0.3373 & 0.1221 & 0.4066 & 0.0460 & 0.0085 & 0.0482 & 0.0151 & 0.0025 & 0.0150 & 0.0020 & 0.0011 & 0.0015 \\
\hline
\end{tabular}


mates of limb masses (and the centre of masses of individual segments) from convex hull modelling than previous methods using just the bones. We supported this presumption by conducting validation tests on a modern lion's body segments, using multiple methods. By doing the reconstructions of the skeleton, segmental inertial properties, and in combination with the musculature data, it was possible to create a full musculoskeletal reconstruction. In addition, our reconstructions of the musculature allow for body composition estimates for $P$. atrox for the first time. Whilst the reconstruction here was carried out mainly in freely available software (e.g., Meshlab) with licensed software used only for the CT scan segmentation, it is entirely possible to carry out future reconstructions only in open source software (e.g., SPIERS; Sutton et al., 2012), expanding the accessibility of this methodology to researchers worldwide.

\section{ACKNOWLEDGEMENTS}

This work was funded by Leverhulme Trust grant RPG 2013-124 to A. Goswami (UCL) and J.R. Hutchinson (RVC). We thank M. Randau (UCL) for preliminary assessment of the specimen, A. Farrell from The George C. Page Museum, and G. Takeuchi and L. Chiappe from the NHMLA for allowing access to this specimen and facilitating its loan for scanning, and N. Ives and G. Stupian from The Aerospace Corporation for scanning this specimen. We finally thank two anonymous reviewers for their comments that improved this paper.

\section{REFERENCES}

Allen, V., Bates, K.T., Li, Z., and Hutchinson, J.R. 2013. Linking the evolution of body shape and locomotor biomechanics in bird-line archosaurs. Nature, 497:104-107. doi:10.1038/nature12059

Allen, V., Paxton, H., and Hutchinson, J.R. 2009. Variation in center of mass estimates for extant sauropsids and its importance for reconstructing inertial properties of extinct archosaurs. The Anatomical Record, 292:1442-1461. doi:10.1002/ar.20973

Anyonge, W. 1993. Body mass in large extant and extinct carnivores. Journal of Zoology, 231:339-350. doi:10.1111/j.1469-7998.1993.tb01922.x

Barnett,R., Mendoza, M.L.Z., Soares, A.E.R., Ho, S.Y.W., Zazula, G., Yamaguchi, N., Shapiro, B., Kirillova, I.V., Larson, G., and Gilbert, M.T.P. 2016. Mitogenomics of the extinct cave lion, Panthera spelaea (Goldfuss, 1810), resolve its position within the Panthera cats. Open Quaternary, 2. doi:10.5334/oq.24
Barnett, R., Shapiro, B., Barnes, I., Ho, S.Y., Burger, J., Yamaguchi, N., Higham, T.F., Wheeler, H.T., Rosendahl, W., Sher, A.V., Sotnikova, M., Kuznetsova, T., Baryshnikov, G.F., Martin, L.D., Harington, C.R., Burns, J.A., and Cooper, A. 2009. Phylogeography of lions (Panthera leo ssp.) reveals three distinct taxa and a late Pleistocene reduction in genetic diversity. Molecular Ecology, 18:1668-1677. doi:10.1111/j.1365-294X.2009.04134.x

Basu, C., Falkingham, P.L., and Hutchinson, J.R. 2016. The extinct, giant giraffid Sivatherium giganteum: skeletal reconstruction and body mass estimation. Biology Letters, 12. doi:10.1098/rsbl.2015.0940

Bates, K.T., Mannion, P.D., Falkingham, P.L., Brusatte, S.L., Hutchinson, J.R., Otero, A., Sellers, W.I., Sullivan, C., Stevens, K.A., and Allen, V. 2016. Temporal and phylogenetic evolution of the sauropod dinosaur body plan. Royal Society Open Science, 3:150636.

Bates, K.T., Manning, P.L., Hodgetts, D., and Sellers, W.I. 2009. Estimating mass properties of dinosaurs using laser imaging and 3D computer modelling. PLOS ONE, 4:e4532. doi:10.1371/journal.pone.0004532

Brassey, C.A. and Sellers, W.I. 2014. Scaling of convex hull volume to body mass in modern primates, nonprimate mammals and birds. PLoS ONE, 9:e91691. doi:10.1371/journal.pone.0091691

Brassey, C.A., O'Mahoney, T.G., Kitchener, A.C., Manning, P.L., and Sellers, W.I. 2016. Convex-hull mass estimates of the dodo (Raphus cucullatus): application of a CT-based mass estimation technique. PeerJ, 4:e1432.

Bryant, H.N. and Seymour, K.L. 1990. Observations and comments on the reliability of muscle reconstruction in fossil vertebrates. Journal of Morphology, 206:109117. doi:10.1002/jmor.1052060111

Christiansen, P. and Harris, J. 2009. Craniomandibular morphology and phylogenetic affinities of Panthera atrox: implications for the evolution and paleobiology of the lion lineage. Journal of Vertebrate Paleontology, 29:934-945.

Cuff, A.R. and Rayfield, E.J. 2015. Retrodeformation and muscular reconstruction of ornithomimosaurian dinosaur crania. PeerJ, 3:e1093. doi:10.7717/peerj.1093

Cuff, A.R., Sparkes, E.L., Randau, M., Pierce, S.E., Kitchener, A.C., Goswami, A., and Hutchinson, J.R. 2016a. The scaling of postcranial muscles in cats (Felidae) I: forelimb, cervical, and thoracic muscles. Journal of Anatomy. doi:10.1111/joa.12477

Cuff, A.R., Sparkes, E.L., Randau, M., Pierce, S.E., Kitchener, A.C., Goswami, A., and Hutchinson, J.R. 2016b. The scaling of postcranial muscles in cats (Felidae) II: hindlimb and lumbosacral muscles. Journal of Anatomy. doi:10.1111/joa.12474 
Davis, D.D. 1962. Allometric relationships in lions vs. domestic cats. Evolution, 16:505-514.

Doube, M., Wiktorowicz Conroy, A., Christiansen, P., Hutchinson, J.R., and Shefelbine, S. 2009. Threedimensional geometric analysis of felid limb bone allometry. PLoS One, 4(3):e1742.

Fuller, B.T., Fahrni, S.M., Harris, J.M., Farrell, A.B., Coltrain, J.B., Gerhart, L.M., Ward, J.K., Taylor, R.E., and Southon, J.R. 2014. Ultrafiltration for asphalt removal from bone collagen for radiocarbon dating and isotopic analysis of Pleistocene fauna at the tar pits of Rancho La Brea, Los Angeles, California. Quaternary Geochronology, 22:85-98. doi:10.1016/j.quageo.2014.03.002

Grand, T.I. 1977. Body weight: its relation to tissue composition, segment distribution, and motor function. I. Interspecific comparisons. American Journal of Physical Anthropology, 47:211-240. doi:10.1002/ajpa.1330470204

Hutchinson, J.R., Bates, K.T., Molnar, J., Allen, V., and Makovicky, P.J. 2011. A computational analysis of limb and body dimensions in Tyrannosaurus rex with implications for locomotion, ontogeny, and growth. PLOS ONE, 6:e26037. doi:10.1371/journal.pone.0026037

Jeffery, N.S., Stephenson, R.S., Gallagher, J.A., Jarvis, J.C., and Cox, P.G. 2011. Micro-computed tomography with iodine staining resolves the arrangement of muscle fibres. Journal of Biomechanics, 44:189-192. doi:10.1016/j.jbiomech.2010.08.027

Kelly, F.C. 1961. lodine in medicine and pharmacy since its discovery-1811-1961. Proceedings of the Royal Society: Medicine, 54:831-836.

Lauten, S.D., Cox, N.R., Baker, G.H., Painter, D.J., Morrison, N.E., and Baker, H.J. 2000. Body composition of growing and adult cats as measured by use of dual energy X-ray absorptiometry. Comparative Medicine, 50:175-183.

Lautenschlager, S. 2013. Cranial myology and bite force performance of Erlikosaurus andrewsi: a novel approach for digital muscle reconstructions. Journal of Anatomy, 222:260-272. doi:10.1111/joa.12000

Leidy, J. 1853. Description of an extinct species of American lion: Felis atrox. Transactions of the American Philosophical Society, 10:319-321.

Mazák, J.H., Christiansen, P., and Kitchener, A.C. 2011. Oldest known pantherine skull and evolution of the tiger. PLOS ONE, 6:e25483.

doi:10.1371/journal.pone.0025483

Meachen-Samuels, J. and Van Valkenburgh, B. 2009. Forelimb indicators of prey-size preference in the Felidae. Journal of Morphology, 270:729-744. doi:10.1002/jmor.10712

Munday, H.S., Earle, K.E., and Anderson, P. 1994 Changes in the body composition of the domestic shorthaired cat during growth and development. Journal of Nutrition, 124:2622S-2623S.

Persons IV, W.S., Currie, P.J., and Norell, M.A. 2013. Oviraptorosaur tail forms and functions. Acta Palaeontologica Polonica, 59. doi:10.4202/app.2012.0093.

Pitts, G.C. and Bullard, T.R. 1968. Some interspecific aspects of body composition in mammals, p. 45-70. Body Composition in Animals and Man. National Academy of Science, Washington, D.C.

Randau, M., Goswami, A., Hutchinson, J.R., Cuff, A.R., and Pierce, S.E. 2016. Cryptic complexity in felid vertebral evolution: shape differentiation and allometry of the axial skeleton. Zoological Journal of the Linnean Society, 178:183-202. doi:10.1111/zoj.12403

Sellers, W.I., Hepworth-Bell, J., Falkingham, P.L., Bates, K.T., Brassey, C.A., Egerton, V.M., and Manning, P.L. 2012. Minimum convex hull mass estimations of complete mounted skeletons. Biology Letters, 8:842845. doi:10.1098/rsbl.2012.0263

Smith, R.J. 2002. Estimation of body mass in palaeontology. Journal of Human Evolution, 43:271-287. doi:10.1006/jhev.2002.0573

Sorkin, B. 2008. A biomechanical constraint on body mass in terrestrial mammalian predators. Lethaia, 41:333-347. doi:10.1111/j.1502-3931.2007.00091.x

Sutton, M.D., Garwood, R.J., Siveter, D.J., and Siveter, D.J. 2012. SPIERS and VAXML: A software toolkit for tomographic visualisation and a format for virtual specimen interchange. Palaeontologia electronica, 15.2.5T:1-14 palaeo-electronica.org/content/issue-22012-technical-articles/226-virtual-palaeontologytoolkit

Witmer, L.M. 1995. The extant phylogenetic bracket and the importance of reconstructing soft tissues in fossils, p. 19-33. In Thomason, J.J. (ed.), Functional morphology in vertebrate paleontology. Cambridge University Press, New York. 


\section{APPENDIX 1.}

Element and specimen numbers for the reconstruction of Panthera atrox.

\begin{tabular}{|c|c|}
\hline Specimen number & Element \\
\hline LACMP23-555 & Skull \\
\hline LACMP23-4819 & $R$ dentary \\
\hline LACMP23-3874 & C1 \\
\hline LACMP23-3944 & $\mathrm{C} 2$ \\
\hline LACMP23-3794 & $\mathrm{C} 3$ \\
\hline LACMP23-1243 & $\mathrm{C} 4$ \\
\hline LACMP23-3857 & C5 \\
\hline LACMP23-1193 & $\mathrm{C} 6$ \\
\hline LACMP23-4434 & $\mathrm{C} 7$ \\
\hline LACMP23-666 & T1 (T2 replicated) \\
\hline LACMP23-666 & $\mathrm{T} 2$ \\
\hline LACMP23-3719 & $\mathrm{T} 3$ \\
\hline LACMP23-3764 & $\mathrm{T} 4$ \\
\hline LACMP23-3764 & T5 (T4 replicated) \\
\hline LACMP23-3765 & T6 \\
\hline LACMP23-3765 & T7 (T6 replicated) \\
\hline LACMP23-3754 & T8 \\
\hline LACMP23-3715 & T9 \\
\hline LACMP2458-19 & T10 (“skeleton 2") \\
\hline LACMP23-3722 & $\mathrm{T} 11$ \\
\hline LACMP23-9667 & $\mathrm{T} 12$ \\
\hline LACMP23-3781 & $\mathrm{T} 13$ \\
\hline LACMP23-3875 & L1 \\
\hline LACMP23-3879 & L2 \\
\hline LACMP23-3894 & L3 \\
\hline LACMP23-3919 & L4 \\
\hline LACMP23-4027 & L5 \\
\hline LACMP23-3887 & L6 \\
\hline LACMP23-3924 & L7 \\
\hline LACMP23-3927 & Sacrum \\
\hline LACMP23-3700 & Right scapula \\
\hline LACMP23-1111 & Left humerus \\
\hline LACMP23-693 & Left radius \\
\hline LACMP23-3694 & Left ulna \\
\hline LACMP23-8741 & Right innominate \\
\hline LACMP23-918 & Left femur \\
\hline LACMP23-3696 & Left tibia \\
\hline NMS.Z.2015.128 & Ribs, tail, manus, pes \\
\hline
\end{tabular}




\section{APPENDIX 2.}

Scaling equations for the forelimb muscles from Cuff et al. (2016a) and calculated muscle belly lengths for the mean, lower, and upper bounds of muscles for Panthera atrox. Serrat. vent. cerv. $=\mathrm{m}$. serratus ventralis cervicus, Serrat. vent. thor. $=\mathrm{m}$. serratus ventralis thoracis, Abd. dig. $1=$ $\mathrm{m}$. abductor digiti 1. Ext. $=$ extensor, Flex. $=$ flexor .

\begin{tabular}{|c|c|c|c|c|c|c|c|}
\hline Muscle & Slope & $\begin{array}{c}\text { Lower } \\
\text { Limit }\end{array}$ & Upper Limit & Intercept & Mean & Lower & Upper \\
\hline Latissimus dorsi & 0.245 & 0.155 & 0.386 & -0.757 & 0.646 & 0.400 & 1.374 \\
\hline Trapezius cervicis & 0.447 & 0.168 & 1.19 & -1.46 & 0.379 & 0.085 & 19.92 \\
\hline Trapezius thoracis & 0.244 & 0.135 & 0.440 & -1.13 & 0.275 & 0.154 & 0.783 \\
\hline Rhomboideus capitis & 0.419 & 0.174 & 1.01 & -1.34 & 0.428 & 0.116 & 9.804 \\
\hline Rhomboideus cervicis & 0.340 & 0.147 & 0.782 & -1.43 & 0.230 & 0.082 & 2.429 \\
\hline Rhomboideus thoracis & 0.283 & 0.173 & 0.464 & -1.35 & 0.204 & 0.113 & 0.538 \\
\hline Omotransversarius & 0.250 & 0.201 & 0.312 & -1.04 & 0.350 & 0.268 & 0.487 \\
\hline Cleidocephalicus & 0.272 & 0.180 & 0.412 & -1.02 & 0.405 & 0.248 & 0.853 \\
\hline Cleidobrachialis & 0.299 & 0.238 & 0.376 & -1.17 & 0.336 & 0.242 & 0.507 \\
\hline Serrat. Vent. Cerv. & 0.244 & 0.186 & 0.321 & -1.18 & 0.244 & 0.179 & 0.368 \\
\hline Serrat. Vent. Thor. & 0.267 & 0.145 & 0.493 & -1.24 & 0.240 & 0.125 & 0.801 \\
\hline Pectoralis superficialis & 0.307 & 0.225 & 0.418 & -1.14 & 0.372 & 0.241 & 0.674 \\
\hline Pectoralis profundus & 0.395 & 0.236 & 0.663 & -1.11 & 0.642 & 0.274 & 2.672 \\
\hline Supraspinatus & 0.327 & 0.268 & 0.398 & -1.22 & 0.344 & 0.252 & 0.505 \\
\hline Infraspinatus & 0.265 & 0.194 & 0.363 & -1.20 & 0.261 & 0.178 & 0.440 \\
\hline Deltoideus acromion & 0.297 & 0.231 & 0.381 & -1.42 & 0.184 & 0.130 & 0.289 \\
\hline Deltoideus spinous & 0.267 & 0.245 & 0.292 & -1.33 & 0.195 & 0.173 & 0.222 \\
\hline Teres major & 0.286 & 0.232 & 0.353 & -1.21 & 0.286 & 0.214 & 0.408 \\
\hline Subscapularis & 0.279 & 0.213 & 0.365 & -1.24 & 0.254 & 0.179 & 0.403 \\
\hline Teres minor & 0.356 & 0.154 & 0.819 & -1.87 & 0.091 & 0.031 & 1.076 \\
\hline Coracobrachialis & 1.09 & 0.468 & 2.54 & -2.72 & 0.644 & 0.023 & 1491 \\
\hline Triceps longus & 0.417 & 0.173 & 1.005 & -1.43 & 0.348 & 0.095 & 7.992 \\
\hline Triceps lateralis & 0.249 & 0.198 & 0.313 & -1.13 & 0.277 & 0.211 & 0.389 \\
\hline Triceps medius & 0.277 & 0.199 & 0.385 & -1.24 & 0.253 & 0.167 & 0.452 \\
\hline Triceps accessory & 0.308 & 0.269 & 0.352 & -1.26 & 0.281 & 0.229 & 0.357 \\
\hline Biceps brachi & 0.259 & 0.214 & 0.315 & -1.19 & 0.257 & 0.201 & 0.346 \\
\hline Brachialis & 0.412 & 0.213 & 0.794 & -1.48 & 0.297 & 0.103 & 2.279 \\
\hline Anconeus & 0.301 & 0.225 & 0.404 & -1.48 & 0.165 & 0.110 & 0.286 \\
\hline Ext. carpi radialis & 0.305 & 0.224 & 0.415 & -1.22 & 0.310 & 0.201 & 0.558 \\
\hline Ext. digitorum communis & 0.296 & 0.134 & 0.653 & -1.31 & 0.236 & 0.100 & 1.587 \\
\hline Ext. digitorum lateralis & 0.575 & 0.270 & 1.23 & -1.72 & 0.415 & 0.081 & 13.3 \\
\hline Ext. carpi ulnaris & 0.287 & 0.195 & 0.423 & -1.24 & 0.264 & 0.161 & 0.544 \\
\hline Flex. carpi ulnaris ulnar & 0.264 & 0.162 & 0.432 & -1.19 & 0.262 & 0.151 & 0.641 \\
\hline Flex. carpi ulnaris humeral & 0.275 & 0.185 & 0.409 & -1.17 & 0.295 & 0.182 & 0.604 \\
\hline Brachioradialis & 1.37 & 0.676 & 2.77 & -2.79 & 2.410 & 0.060 & 4289 \\
\hline Supinator & 0.316 & 0.220 & 0.454 & -1.57 & 0.147 & 0.088 & 0.307 \\
\hline Pronator teres & 0.316 & 0.232 & 0.431 & -1.40 & 0.216 & 0.138 & 0.398 \\
\hline Pronator quadratus & 0.497 & 0.326 & 0.756 & -1.75 & 0.254 & 0.102 & 1.014 \\
\hline Flex. carpi radialis & 0.305 & 0.256 & 0.363 & -1.29 & 0.259 & 0.199 & 0.353 \\
\hline Flex. digitorum complex & 0.237 & 0.163 & 0.345 & -1.10 & 0.284 & 0.191 & 0.505 \\
\hline Abd. Dig. 1 & 0.576 & 0.388 & 0.856 & -1.71 & 0.418 & 0.153 & 1.859 \\
\hline
\end{tabular}




\section{APPENDIX 3.}

Scaling equations for the forelimb muscles from Cuff et al. (2016a) and calculated tendon lengths for the mean, lower, and upper bounds of muscles for Panthera atrox. Abd. dig. $1=\mathrm{m}$. abductor digiti 1 . Ext. $=$ extensor, Flex. $=$ flexor.

\begin{tabular}{|c|c|c|c|c|c|c|c|}
\hline Muscle & Slope & $\begin{array}{c}\text { Lower } \\
\text { Limit }\end{array}$ & Upper Limit & Intercept & Mean & Lower & Upper \\
\hline Cleidobrachialis & 0.945 & 0.433 & 2.06 & -3.04 & 0.140 & 0.009 & 54.70 \\
\hline Supraspinatus & 0.719 & 0.032 & 16.2 & -3.01 & 0.045 & 0.001 & $2.44 \times 10^{34}$ \\
\hline Infraspinatus & 1.18 & 0.751 & 1.84 & -3.42 & 0.203 & 0.021 & 7.029 \\
\hline Deltoideus spinous & 1.29 & 0.072 & 22.9 & -3.92 & 0.113 & 0.000 & $1.21 \times 10^{49}$ \\
\hline Teres major & -0.687 & -1.649 & -0.286 & -1.14 & 0.002 & 0.000 & 0.016 \\
\hline Subscapularis & 0.350 & 0.199 & 0.614 & -2.46 & 0.022 & 0.010 & 0.092 \\
\hline Triceps longus & 0.727 & 0.420 & 1.26 & -2.57 & 0.130 & 0.025 & 2.206 \\
\hline Triceps lateralis & 1.03 & 0.387 & 2.77 & -3.39 & 0.101 & 0.003 & 1029 \\
\hline Triceps medius & 0.598 & 0.225 & 1.59 & -2.25 & 0.136 & 0.019 & 26.37 \\
\hline Biceps brachi & 0.289 & 0.168 & 0.497 & -1.66 & 0.102 & 0.054 & 0.310 \\
\hline Brachialis & 0.530 & 0.285 & 0.983 & -2.46 & 0.059 & 0.016 & 0.658 \\
\hline Ext. carpi radialis & 0.336 & 0.205 & 0.552 & -1.57 & 0.163 & 0.081 & 0.515 \\
\hline Ext. digitorum communis & -0.661 & -1.580 & -0.276 & -0.313 & 0.014 & 0.000 & 0.111 \\
\hline Ext. digitorum lateralis & 0.242 & 0.123 & 0.475 & -1.332 & 0.169 & 0.090 & 0.588 \\
\hline Ext. carpi ulnaris & 0.289 & 0.134 & 0.624 & -1.457 & 0.163 & 0.071 & 0.977 \\
\hline Flex. carpi ulnaris ulnar & -0.310 & -0.823 & -0.117 & -0.964 & 0.021 & 0.001 & 0.058 \\
\hline Flex. carpi ulnaris humeral & 0.534 & 0.111 & 2.575 & -2.20 & 0.108 & 0.011 & 5765 \\
\hline Supinator & -1.37 & -8.50 & -0.222 & 0.503 & 0.002 & 0.000 & 0.974 \\
\hline Pronator quadratus & 0.552 & 0.154 & 1.987 & -2.41 & 0.073 & 0.009 & 154.6 \\
\hline Flex. carpi radialis & 0.212 & 0.088 & 0.511 & -1.58 & 0.081 & 0.042 & 0.399 \\
\hline Flex. digitorum complex & 0.262 & 0.151 & 0.456 & -1.36 & 0.177 & 0.098 & 0.496 \\
\hline Abd. Dig. 1 & 0.691 & 0.365 & 1.308 & -2.25 & 0.223 & 0.039 & 6.010 \\
\hline
\end{tabular}




\section{APPENDIX 4.}

Scaling equations for the forelimb muscles from Cuff et al. (2016a) and calculated muscle belly masses for the mean, lower, and upper bounds of muscles for Panthera atrox. Serrat. vent. cerv. $=\mathrm{m}$. serratus ventralis cervicus, Serrat. vent. thor. $=\mathrm{m}$. serratus ventralis thoracis, Abd. dig. $1=$ $\mathrm{m}$. abductor digiti 1. Ext. $=$ extensor, Flex. $=$ flexor.

\begin{tabular}{|c|c|c|c|c|c|c|c|}
\hline Muscle & Slope & $\begin{array}{c}\text { Lower } \\
\text { Limit }\end{array}$ & Upper Limit & Intercept & Mean & Lower & Upper \\
\hline Latissimus dorsi & 1.12 & 0.993 & 1.26 & -2.34 & 1.776 & 0.906 & 3.792 \\
\hline Trapezius cervicis & 1.05 & 0.913 & 1.22 & -3.08 & 0.229 & 0.108 & 0.543 \\
\hline Trapezius thoracis & 1.07 & 0.867 & 1.32 & -3.09 & 0.242 & 0.083 & 0.910 \\
\hline Rhomboideus capitis & 1.27 & 0.877 & 1.84 & -3.58 & 0.232 & 0.028 & 4.913 \\
\hline Rhomboideus cervicis & 1.15 & 0.859 & 1.55 & -3.02 & 0.444 & 0.093 & 3.618 \\
\hline Rhomboideus thoracis & 1.07 & 0.734 & 1.57 & -3.30 & 0.156 & 0.025 & 2.231 \\
\hline Omotransversarius & 1.08 & 0.877 & 1.34 & -3.28 & 0.169 & 0.056 & 0.656 \\
\hline Cleidocephalicus & 1.18 & 0.874 & 1.58 & -3.04 & 0.484 & 0.096 & 4.238 \\
\hline Cleidobrachialis & 1.14 & 0.939 & 1.39 & -2.94 & 0.509 & 0.171 & 1.915 \\
\hline Serrat. Vent. Cerv. & 0.977 & 0.702 & 1.36 & -2.55 & 0.523 & 0.121 & 4.027 \\
\hline Serrat. Vent. Thor. & 0.949 & 0.779 & 1.16 & -2.46 & 0.552 & 0.223 & 1.672 \\
\hline Pectoralis superficialis & 1.22 & 0.917 & 1.63 & -3.08 & 0.567 & 0.111 & 4.987 \\
\hline Pectoralis profundus & 1.07 & 0.887 & 1.29 & -2.20 & 1.923 & 0.720 & 6.290 \\
\hline Supraspinatus & 1.02 & 0.844 & 1.23 & -2.36 & 1.001 & 0.395 & 3.082 \\
\hline Infraspinatus & 0.991 & 0.799 & 1.23 & -2.45 & 0.699 & 0.251 & 2.491 \\
\hline Deltoideus acromion & 1.04 & 0.881 & 1.24 & -3.21 & 0.162 & 0.068 & 0.451 \\
\hline Deltoideus spinous & 1.08 & 0.877 & 1.33 & -3.22 & 0.190 & 0.064 & 0.725 \\
\hline Teres major & 1.07 & 0.921 & 1.25 & -2.74 & 0.554 & 0.246 & 1.429 \\
\hline Subscapularis & 0.963 & 0.797 & 1.16 & -2.41 & 0.670 & 0.276 & 1.959 \\
\hline Teres minor & 0.982 & 0.796 & 1.21 & -3.73 & 0.035 & 0.013 & 0.120 \\
\hline Coracobrachialis & 1.55 & 0.734 & 3.26 & -4.46 & 0.133 & 0.002 & 1233 \\
\hline Triceps longus & 1.06 & 0.922 & 1.23 & -2.27 & 1.562 & 0.732 & 3.744 \\
\hline Triceps lateralis & 1.05 & 0.906 & 1.22 & -2.67 & 0.582 & 0.270 & 1.417 \\
\hline Triceps medius & 1.05 & 0.840 & 1.31 & -3.14 & 0.197 & 0.064 & 0.804 \\
\hline Triceps accessory & 0.968 & 0.758 & 1.23 & -3.15 & 0.123 & 0.040 & 0.513 \\
\hline Biceps brachi & 1.06 & 0.895 & 1.25 & -2.73 & 0.531 & 0.223 & 1.485 \\
\hline Brachialis & 1.00 & 0.652 & 1.54 & -3.19 & 0.138 & 0.021 & 2.473 \\
\hline Anconeus & 1.05 & 0.801 & 1.37 & -3.57 & 0.072 & 0.019 & 0.404 \\
\hline Ext. carpi radialis & 1.03 & 0.822 & 1.30 & -3.09 & 0.201 & 0.065 & 0.828 \\
\hline Ext. digitorum communis & 1.17 & 0.929 & 1.48 & -3.45 & 0.186 & 0.051 & 0.945 \\
\hline Ext. digitorum lateralis & 1.02 & 0.761 & 1.36 & -3.63 & 0.054 & 0.014 & 0.300 \\
\hline Ext. carpi ulnaris & 1.10 & 0.681 & 1.78 & -3.66 & 0.077 & 0.008 & 2.868 \\
\hline Flex. carpi ulnaris ulnar & 1.19 & 0.814 & 1.74 & -3.61 & 0.139 & 0.019 & 2.628 \\
\hline Flex. carpi ulnaris humeral & 1.10 & 0.933 & 1.30 & -3.34 & 0.162 & 0.066 & 0.474 \\
\hline Brachioradialis & 1.49 & 1.261 & 1.75 & -4.11 & 0.218 & 0.065 & 0.900 \\
\hline Supinator & 1.02 & 0.747 & 1.40 & -3.77 & 0.039 & 0.009 & 0.292 \\
\hline Pronator teres & 1.03 & 0.836 & 1.28 & -3.29 & 0.128 & 0.044 & 0.476 \\
\hline Pronator quadratus & 1.22 & 0.925 & 1.61 & -3.98 & 0.071 & 0.015 & 0.574 \\
\hline Flex. carpi radialis & 0.929 & 0.792 & 1.09 & -3.39 & 0.058 & 0.028 & 0.138 \\
\hline Flex. digitorum complex & 0.998 & 0.877 & 1.13 & -2.61 & 0.499 & 0.262 & 1.038 \\
\hline Abd. Dig. 1 & 0.861 & 0.566 & 1.31 & -3.41 & 0.039 & 0.008 & 0.425 \\
\hline
\end{tabular}




\section{APPENDIX 5.}

Scaling equations for the forelimb muscles from Cuff et al. (2016a) and calculated tendon masses for the mean, lower, and upper bounds of muscles for Panthera atrox. Abd. dig. $1=\mathrm{m}$. abductor digiti 1, Ext. $=$ extensor, Flex. $=$ flexor.

\begin{tabular}{lccccccc}
\hline \multicolumn{1}{c}{ Muscle } & Slope & Lower Limit & Upper Limit & Intercept & Mean & Lower & Upper \\
\hline Cleidobrachialis & -2.71 & -9.826 & -0.748 & 0.836 & 0.000 & 0.000 & 0.127 \\
Supraspinatus & 0.651 & 0.087 & 4.88 & -4.39 & 0.001 & 0.000 & $8.38 \times 10^{6}$ \\
Infraspinatus & 1.289 & 0.636 & 2.61 & -4.40 & 0.038 & 0.001 & 44.46 \\
Deltoideus spinous & -0.349 & -5.351 & -0.023 & -2.54 & 0.000 & 0.000 & 0.003 \\
Teres major & 0.621 & 0.376 & 1.027 & -4.41 & 0.001 & 0.000 & 0.009 \\
Triceps longus & 0.852 & 0.431 & 1.68 & -4.22 & 0.006 & 0.001 & 0.470 \\
Triceps lateralis & 1.02 & 0.627 & 1.65 & -4.65 & 0.005 & 0.001 & 0.154 \\
Triceps medius & 1.70 & 0.772 & 3.75 & -5.94 & 0.010 & 0.000 & 548.4 \\
Biceps brachi & 0.933 & 0.748 & 1.16 & -4.10 & 0.012 & 0.004 & 0.040 \\
Brachialis & 0.943 & 0.495 & 1.80 & -4.71 & 0.003 & 0.000 & 0.287 \\
Ext. carpi radialis & 0.915 & 0.765 & 1.09 & -4.24 & 0.008 & 0.003 & 0.019 \\
Ext. digitorum communis & 1.44 & 0.970 & 2.12 & -4.46 & 0.074 & 0.006 & 2.906 \\
Ext. digitorum lateralis & 0.958 & 0.722 & 1.27 & -4.32 & 0.008 & 0.002 & 0.042 \\
Ext. carpi ulnaris & 0.833 & 0.455 & 1.52 & -4.23 & 0.005 & 0.001 & 0.199 \\
Flex. carpi ulnaris ulnar & 1.16 & 0.743 & 1.82 & -5.21 & 0.003 & 0.000 & 0.101 \\
Flex. carpi ulnaris humeral & 0.984 & 0.643 & 1.51 & -5.08 & 0.002 & 0.000 & 0.026 \\
Supinator & 1.57 & 0.251 & 9.79 & -6.08 & 0.004 & 0.000 & $4.09 \times 10^{6}$ \\
Pronator quadratus & 0.953 & 0.310 & 2.93 & -4.58 & 0.004 & 0.000 & 162.0 \\
Flex. carpi radialis & 0.660 & 0.450 & 0.967 & -4.28 & 0.002 & 0.001 & 0.009 \\
Flex. digitorum complex & 0.943 & 0.692 & 1.29 & -3.24 & 0.087 & 0.023 & 0.541 \\
Abd. Dig. 1 & 0.730 & 0.403 & 1.32 & -4.24 & 0.003 & 0.000 & 0.066 \\
\hline
\end{tabular}


APPENDIX 6.

Scaling equations for the hindlimb muscles from Cuff et al. (2016b) and calculated muscle belly lengths for the mean, lower, and upper bounds of muscles for Panthera atrox. Gastroc. = gastrocnemius, dig. $=$ digitorum, supefic. $=$ superficialis.

\begin{tabular}{|c|c|c|c|c|c|c|c|}
\hline Muscle & Slope & $\begin{array}{c}\text { Lower } \\
\text { LimitLower } \\
\text { Limit }\end{array}$ & Upper Limit & Intercept & Mean & Lower & Upper \\
\hline Biceps femoris & 0.264 & 0.172 & 0.406 & -0.988 & 0.420 & 0.257 & 0.895 \\
\hline Caudofemoralis & 0.281 & 0.185 & 0.426 & -1.079 & 0.373 & 0.223 & 0.811 \\
\hline Sartorius & 0.327 & 0.258 & 0.414 & -0.941 & 0.654 & 0.453 & 1.040 \\
\hline Tensor fascia latae & 0.292 & 0.221 & 0.387 & -1.398 & 0.190 & 0.130 & 0.315 \\
\hline Vastus lateralis & 0.286 & 0.232 & 0.352 & -1.072 & 0.389 & 0.293 & 0.553 \\
\hline Rectus femoris & 0.366 & 0.204 & 0.658 & -1.227 & 0.419 & 0.176 & 1.984 \\
\hline Vastus medius & 0.268 & 0.210 & 0.342 & -1.077 & 0.350 & 0.257 & 0.519 \\
\hline Vastus intermedius & 0.554 & 0.264 & 1.164 & -1.597 & 0.486 & 0.103 & 12.60 \\
\hline Semitendinosus & 0.279 & 0.242 & 0.322 & -0.980 & 0.464 & 0.381 & 0.583 \\
\hline Semimembranosus & 0.564 & 0.270 & 1.178 & -1.451 & 0.718 & 0.150 & 18.95 \\
\hline Gracilis & 0.244 & 0.132 & 0.449 & -1.155 & 0.257 & 0.142 & 0.770 \\
\hline Gluteus superficialis & 0.321 & 0.213 & 0.484 & -1.479 & 0.184 & 0.103 & 0.439 \\
\hline Gluteus medius & 0.345 & 0.290 & 0.412 & -1.405 & 0.249 & 0.185 & 0.354 \\
\hline Gluteus profundus & 0.353 & 0.255 & 0.489 & -1.454 & 0.231 & 0.137 & 0.476 \\
\hline Piriformis & 0.167 & 0.101 & 0.276 & -1.432 & 0.090 & 0.063 & 0.162 \\
\hline Gemelli & 0.380 & 0.188 & 0.769 & -1.693 & 0.154 & 0.055 & 1.226 \\
\hline Quadratus femoris & 0.301 & 0.228 & 0.396 & -1.600 & 0.125 & 0.085 & 0.208 \\
\hline Obturator externus & 0.330 & 0.271 & 0.402 & -1.671 & 0.124 & 0.091 & 0.182 \\
\hline Obturator internus & 0.288 & 0.172 & 0.480 & -1.595 & 0.118 & 0.064 & 0.329 \\
\hline Pectineus & 0.455 & 0.234 & 0.883 & -1.626 & 0.268 & 0.083 & 2.625 \\
\hline Adductor magnus & 0.305 & 0.198 & 0.471 & -1.114 & 0.392 & 0.221 & 0.900 \\
\hline Adductor brevis & 0.310 & 0.175 & 0.551 & -1.388 & 0.214 & 0.104 & 0.773 \\
\hline Iliacus & 1.388 & 0.090 & 21.318 & -3.465 & 0.564 & 0.001 & $8.35 \times 10^{4}$ \\
\hline Psoas major & 0.384 & 0.256 & 0.575 & -1.142 & 0.558 & 0.283 & 1.547 \\
\hline Psoas minor & 0.318 & 0.201 & 0.504 & -1.165 & 0.373 & 0.200 & 1.004 \\
\hline Gastroc. lateralis & 0.327 & 0.219 & 0.490 & -1.235 & 0.334 & 0.187 & 0.796 \\
\hline Gastroc. medius & 0.262 & 0.216 & 0.317 & -1.142 & 0.291 & 0.228 & 0.392 \\
\hline Superfic. dig. flexor & 0.264 & 0.131 & 0.530 & -1.144 & 0.293 & 0.145 & 1.211 \\
\hline Soleus & 0.212 & 0.147 & 0.304 & -1.061 & 0.268 & 0.191 & 0.439 \\
\hline Dig. extensor longus & 0.265 & 0.150 & 0.468 & -1.150 & 0.291 & 0.157 & 0.859 \\
\hline Tibialis cranialis & 0.237 & 0.130 & 0.432 & -1.095 & 0.284 & 0.160 & 0.800 \\
\hline Popliteus & 0.375 & 0.266 & 0.530 & -1.594 & 0.189 & 0.105 & 0.432 \\
\hline Dig. extensor lateralis & 0.265 & 0.196 & 0.359 & -1.282 & 0.215 & 0.149 & 0.354 \\
\hline Peroneus longus & 0.236 & 0.145 & 0.383 & -1.201 & 0.222 & 0.137 & 0.486 \\
\hline Peroneus brevis & 0.192 & 0.112 & 0.330 & -1.144 & 0.200 & 0.130 & 0.400 \\
\hline Deep digital flexor medial & 0.307 & 0.196 & 0.480 & -1.236 & 0.298 & 0.165 & 0.751 \\
\hline Deep digital flexor lateral & 0.406 & 0.171 & 0.965 & -1.430 & 0.324 & 0.092 & 6.383 \\
\hline Tibialis caudalis & 0.413 & 0.256 & 0.666 & -1.522 & 0.272 & 0.118 & 1.046 \\
\hline
\end{tabular}




\section{APPENDIX 7.}

Scaling equations for the hindlimb muscles from Cuff et al. (2016b) and calculated tendon lengths for the mean, lower, and upper bounds of muscles for Panthera atrox. Gastroc. = gastrocnemius, Dig. = digitorum, Supefic. $=$ superficialis.

\begin{tabular}{|c|c|c|c|c|c|c|c|}
\hline Muscle & Slope & Lower Limit & Upper Limit & Intercept & Mean & Lower & Upper \\
\hline Caudofemoralis & 0.496 & 0.304 & 0.812 & -1.612 & 0.345 & 0.123 & 1.854 \\
\hline Tensor fascia latae & 0.330 & 0.160 & 0.679 & -1.298 & 0.293 & 0.119 & 1.880 \\
\hline Rectus femoris & 1.307 & 0.099 & 17.288 & -3.216 & 0.650 & 0.001 & $6.86 \times 10^{3}$ \\
\hline Vastus medius & 0.264 & 0.144 & 0.483 & -2.155 & 0.029 & 0.015 & 0.092 \\
\hline Vastus intermedius & -0.875 & -20.805 & -0.037 & -0.659 & 0.002 & 0.000 & 0.180 \\
\hline Semitendinosus & 0.440 & 0.230 & 0.841 & -1.893 & 0.134 & 0.044 & 1.138 \\
\hline Semimembranosus & 0.467 & 0.162 & 1.348 & -2.446 & 0.043 & 0.008 & 4.746 \\
\hline Gracilis & 0.558 & 0.093 & 3.355 & -2.349 & 0.088 & 0.007 & $2.65 \times 10^{5}$ \\
\hline Gluteus profundus & -0.604 & -3.758 & -0.097 & -0.893 & 0.005 & 0.000 & 0.076 \\
\hline Piriformis & 0.278 & 0.015 & 5.158 & -2.279 & 0.023 & 0.006 & $4.69 \times 10^{9}$ \\
\hline Obturator internus & 0.353 & 0.068 & 1.842 & -1.924 & 0.078 & 0.017 & 220.4 \\
\hline Psoas major & 0.074 & 0.003 & 1.689 & -1.407 & 0.058 & 0.040 & 320.7 \\
\hline Psoas minor & 0.182 & 0.035 & 0.937 & -1.563 & 0.072 & 0.033 & 4.059 \\
\hline Gastroc. lateralis & 0.208 & 0.102 & 0.424 & -1.624 & 0.072 & 0.041 & 0.228 \\
\hline Gastroc. medius & 0.470 & 0.235 & 0.939 & -1.952 & 0.137 & 0.039 & 1.677 \\
\hline Superfic. dig. flexor & 0.887 & 0.369 & 2.134 & -2.483 & 0.373 & 0.023 & 289.5 \\
\hline Soleus & 0.058 & 0.002 & 1.424 & -1.749 & 0.024 & 0.018 & 35.43 \\
\hline Dig. extensor longus & 0.445 & 0.188 & 1.051 & -1.601 & 0.269 & 0.068 & 6.825 \\
\hline Tibialis cranialis & 0.366 & 0.183 & 0.731 & -1.803 & 0.111 & 0.042 & 0.777 \\
\hline Popliteus & 0.564 & 0.075 & 4.223 & -2.329 & 0.095 & 0.007 & $2.85 \times 10^{7}$ \\
\hline Dig. extensor lateralis & 0.427 & 0.245 & 0.745 & -1.484 & 0.320 & 0.121 & 1.747 \\
\hline Peroneus longus & 0.331 & 0.148 & 0.738 & -1.546 & 0.166 & 0.063 & 1.456 \\
\hline Peroneus brevis & 0.648 & 0.239 & 1.753 & -2.117 & 0.242 & 0.027 & 87.82 \\
\hline Deep digital flexor medial & 0.336 & 0.148 & 0.760 & -1.302 & 0.299 & 0.110 & 2.877 \\
\hline Deep digital flexor lateral & 0.525 & 0.272 & 1.015 & -1.550 & 0.465 & 0.120 & 6.322 \\
\hline Tibialis caudalis & 0.313 & 0.132 & 0.740 & -1.469 & 0.180 & 0.069 & 1.759 \\
\hline
\end{tabular}


APPENDIX 8.

Scaling equations for the hindlimb muscles from Cuff et al. (2016b) and calculated muscle belly masses for the mean, lower, and upper bounds of muscles for Panthera atrox. Gastroc. = gastrocnemius, Dig. = digitorum, Supefic. $=$ superficialis.

\begin{tabular}{|c|c|c|c|c|c|c|c|}
\hline Muscle & Slope & Lower Limit & Upper Limit & Intercept & Mean & Lower & Upper \\
\hline Biceps femoris & 0.998 & 0.862 & 1.155 & -2.124 & 1.537 & 0.745 & 3.553 \\
\hline Caudofemoralis & 1.353 & 0.950 & 1.928 & -3.423 & 0.515 & 0.060 & 11.03 \\
\hline Sartorius & 1.090 & 0.956 & 1.242 & -2.636 & 0.775 & 0.380 & 1.745 \\
\hline Tensor fascia latae & 1.240 & 0.976 & 1.575 & -3.138 & 0.542 & 0.133 & 3.236 \\
\hline Vastus lateralis & 0.955 & 0.788 & 1.156 & -2.228 & 0.962 & 0.396 & 2.815 \\
\hline Rectus femoris & 0.964 & 0.841 & 1.103 & -2.391 & 0.693 & 0.361 & 1.462 \\
\hline Vastus medius & 0.924 & 0.732 & 1.165 & -2.452 & 0.487 & 0.175 & 1.769 \\
\hline Vastus intermedius & 0.796 & 0.650 & 0.976 & -2.619 & 0.168 & 0.077 & 0.439 \\
\hline Semitendinosus & 1.093 & 0.929 & 1.286 & -2.697 & 0.684 & 0.285 & 1.915 \\
\hline Semimembranosus & 1.061 & 0.789 & 1.428 & -2.322 & 1.369 & 0.320 & 9.683 \\
\hline Gracilis & 1.213 & 0.767 & 1.917 & -3.082 & 0.534 & 0.050 & 22.90 \\
\hline Gluteus superficialis & 1.053 & 0.832 & 1.334 & -3.257 & 0.153 & 0.047 & 0.681 \\
\hline Gluteus medius & 1.220 & 1.120 & 1.330 & -2.800 & 1.063 & 0.622 & 1.905 \\
\hline Gluteus profundus & 0.906 & 0.743 & 1.106 & -3.147 & 0.090 & 0.037 & 0.261 \\
\hline Piriformis & 0.828 & 0.630 & 1.087 & -2.948 & 0.093 & 0.033 & 0.372 \\
\hline Gemelli & 1.155 & 0.827 & 1.612 & -3.510 & 0.146 & 0.025 & 1.675 \\
\hline Quadratus femoris & 0.785 & 0.556 & 1.109 & -3.160 & 0.046 & 0.013 & 0.256 \\
\hline Obturator externus & 1.085 & 0.909 & 1.295 & -3.288 & 0.168 & 0.066 & 0.516 \\
\hline Obturator internus & 1.063 & 0.784 & 1.441 & -3.214 & 0.178 & 0.040 & 1.331 \\
\hline Pectineus & 0.903 & 0.635 & 1.285 & -3.124 & 0.093 & 0.022 & 0.711 \\
\hline Adductor magnus & 1.056 & 0.729 & 1.530 & -2.374 & 1.181 & 0.206 & 14.8 \\
\hline Adductor brevis & 0.878 & 0.547 & 1.409 & -2.710 & 0.211 & 0.036 & 3.574 \\
\hline Iliacus & 2.272 & 0.456 & 11.327 & -5.532 & 0.538 & 0.000 & $5.12 \times 10^{2}$ \\
\hline Psoas major & 1.172 & 0.849 & 1.619 & -2.821 & 0.785 & 0.140 & 8.520 \\
\hline Psoas minor & 1.098 & 0.801 & 1.505 & -3.159 & 0.242 & 0.050 & 2.131 \\
\hline Gastroc. lateralis & 0.923 & 0.721 & 1.181 & -2.562 & 0.377 & 0.129 & 1.496 \\
\hline Gastroc. medius & 0.874 & 0.737 & 1.036 & -2.545 & 0.302 & 0.146 & 0.718 \\
\hline Superfic. dig. flexor & 0.842 & 0.623 & 1.138 & -2.876 & 0.119 & 0.037 & 0.575 \\
\hline Soleus & 0.850 & 0.669 & 1.080 & -2.880 & 0.123 & 0.047 & 0.419 \\
\hline Dig. extensor longus & 0.902 & 0.527 & 1.544 & -3.166 & 0.084 & 0.011 & 2.577 \\
\hline Tibialis cranialis & 1.025 & 0.725 & 1.449 & -3.046 & 0.213 & 0.043 & 2.00 \\
\hline Popliteus & 0.846 & 0.683 & 1.048 & -3.225 & 0.054 & 0.023 & 0.159 \\
\hline Dig. extensor lateralis & 0.835 & 0.522 & 1.336 & -3.518 & 0.026 & 0.005 & 0.378 \\
\hline Peroneus longus & 1.324 & 0.768 & 2.283 & -3.800 & 0.185 & 0.010 & 30.82 \\
\hline Peroneus brevis & 0.912 & 0.600 & 1.387 & -3.496 & 0.041 & 0.008 & 0.500 \\
\hline Deep digital flexor medial & 1.038 & 0.726 & 1.485 & -3.188 & 0.165 & 0.031 & 1.788 \\
\hline Deep digital flexor lateral & 1.017 & 0.630 & 1.643 & -3.220 & 0.137 & 0.017 & 3.865 \\
\hline Tibialis caudalis & 1.263 & 0.961 & 1.660 & -3.856 & 0.117 & 0.023 & 0.975 \\
\hline
\end{tabular}




\section{APPENDIX 9.}

Scaling equations for the hindlimb muscles from Cuff et al. (2016b) and calculated tendon masses for the mean, lower, and upper bounds of muscles for Panthera atrox. Gastroc. = gastrocnemius, Dig. $=$ digitorum, Supefic. $=$ superficialis.

\begin{tabular}{|c|c|c|c|c|c|c|c|}
\hline Muscle & Slope & Lower Limit & Upper Limit & Intercept & Mean & Lower & Upper \\
\hline Caudofemoralis & 1.190 & 0.455 & 3.111 & -4.484 & 0.019 & 0.000 & 527.3 \\
\hline Tensor fascia latae & 0.964 & 0.690 & 1.347 & -3.599 & 0.043 & 0.010 & 0.333 \\
\hline Rectus femoris & 1.441 & 0.059 & 35.233 & -4.439 & 0.079 & 0.000 & $1.53 \times 10^{77}$ \\
\hline Vastus medius & 1.029 & 0.621 & 1.704 & -4.782 & 0.004 & 0.000 & 0.147 \\
\hline Vastus intermedius & -0.488 & -11.839 & -0.020 & -2.481 & 0.000 & 0.000 & 0.003 \\
\hline Semitendinosus & 0.962 & 0.607 & 1.525 & -4.575 & 0.005 & 0.001 & 0.091 \\
\hline Semimembranosus & 0.750 & 0.419 & 1.342 & -4.321 & 0.003 & 0.000 & 0.061 \\
\hline Gracilis & 1.225 & 0.445 & 3.372 & -4.638 & 0.016 & 0.000 & 1492 \\
\hline Gluteus profundus & 0.574 & 0.176 & 1.876 & -4.360 & 0.001 & 0.000 & 0.971 \\
\hline Piriformis & 0.893 & 0.229 & 3.492 & -4.675 & 0.002 & 0.000 & 2602 \\
\hline Obturator internus & 1.035 & 0.127 & 8.421 & -4.487 & 0.008 & 0.000 & $1.05 \times 10^{15}$ \\
\hline Psoas major & 1.725 & 1.080 & 2.756 & -5.129 & 0.074 & 0.002 & 18.08 \\
\hline Psoas minor & 0.756 & 0.212 & 2.692 & -4.446 & 0.002 & 0.000 & 61.68 \\
\hline Gastroc. lateralis & 1.014 & 0.642 & 1.601 & -4.036 & 0.021 & 0.003 & 0.471 \\
\hline Gastroc. medius & 0.973 & 0.547 & 1.729 & -3.929 & 0.021 & 0.002 & 1.19 \\
\hline Superfic. dig. flexor & 1.710 & 1.153 & 2.536 & -4.468 & 0.311 & 0.016 & 25.49 \\
\hline Soleus & 0.770 & 0.052 & 11.341 & -4.509 & 0.002 & 0.000 & $5.82 \times 10^{21}$ \\
\hline Dig. extensor longus & 1.568 & 1.063 & 2.313 & -4.610 & 0.105 & 0.007 & 5.61 \\
\hline Tibialis cranialis & 1.010 & 0.666 & 1.532 & -4.696 & 0.004 & 0.001 & 0.071 \\
\hline Popliteus & 0.814 & 0.423 & 1.566 & -4.388 & 0.003 & 0.000 & 0.174 \\
\hline Dig. extensor lateralis & 0.829 & 0.595 & 1.155 & -4.389 & 0.003 & 0.001 & 0.019 \\
\hline Peroneus longus & 1.856 & 0.726 & 4.745 & -5.506 & 0.062 & 0.000 & $3.06 \times 10^{5}$ \\
\hline Peroneus brevis & 0.950 & 0.553 & 1.633 & -4.589 & 0.004 & 0.000 & 0.156 \\
\hline Deep digital flexor medial & 1.335 & 0.711 & 2.508 & -4.300 & 0.062 & 0.002 & 32.40 \\
\hline Deep digital flexor lateral & 1.035 & 0.659 & 1.625 & -3.791 & 0.040 & 0.005 & 0.940 \\
\hline Tibialis caudalis & 1.129 & 0.630 & 2.023 & -4.585 & 0.011 & 0.001 & 1.266 \\
\hline
\end{tabular}




\section{APPENDIX 10.}

Scaling equations for the vertebral muscles from Cuff et al. (2016a, 2016b) and calculated muscle belly lengths for the mean, lower, and upper bounds of muscles for Panthera atrox. Longis. $=$ longissimus, lliocost. $=$ iliocostalis, Multifid. $=$ multifidus .

\begin{tabular}{lccccccc}
\hline \multicolumn{1}{c}{ Muscle } & Slope & $\begin{array}{c}\text { Lower } \\
\text { Limit }\end{array}$ & Upper Limit & Intercept & Mean & Lower & Upper \\
\hline Rectus capitis & 0.208 & 0.080 & 0.541 & -1.43 & 0.112 & 0.057 & 0.662 \\
Splenius cervicis & 0.234 & 0.174 & 0.316 & -0.946 & 0.395 & 0.286 & 0.610 \\
Serratus dorsalis cranialis & 0.239 & 0.079 & 0.719 & -1.45 & 0.127 & 0.054 & 1.647 \\
Serratus dorsalis caudalis & 0.186 & 0.070 & 0.496 & -1.50 & 0.085 & 0.046 & 0.444 \\
Semispinalis capitis biventer & 1.36 & 0.683 & 2.71 & -2.55 & 4.009 & 0.108 & 5326 \\
Semispinalis capitis complexus & 0.336 & 0.162 & 0.700 & -1.11 & 0.470 & 0.185 & 3.267 \\
Spinalis cervicis & 0.240 & 0.098 & 0.591 & -1.06 & 0.314 & 0.147 & 2.040 \\
Spinalis thoracis & 0.309 & 0.252 & 0.380 & -0.910 & 0.641 & 0.472 & 0.934 \\
Longissimus capitis & 0.287 & 0.130 & 0.633 & -1.16 & 0.323 & 0.140 & 2.044 \\
Longissimus cervicis & 0.227 & 0.121 & 0.425 & -0.920 & 0.405 & 0.230 & 1.163 \\
Longissimus thoracis & 0.340 & 0.208 & 0.556 & -0.872 & 0.827 & 0.409 & 2.612 \\
Iliocostalis thoracis & 0.266 & 0.183 & 0.386 & -0.809 & 0.640 & 0.412 & 1.215 \\
Multifidis throacis & 0.305 & 0.213 & 0.435 & -0.852 & 0.713 & 0.439 & 1.429 \\
Longis. lumborum & 0.603 & 0.197 & 1.849 & -1.403 & 0.987 & 0.113 & 758.5 \\
Iliocost. lumborum & 0.358 & 0.216 & 0.594 & -1.030 & 0.630 & 0.295 & 2.217 \\
Multifid. lumborum & 0.319 & 0.166 & 0.613 & -0.919 & 0.661 & 0.293 & 3.165 \\
\hline
\end{tabular}

\section{APPENDIX 11.}

Scaling equations for the vertebral muscles from Cuff et al. (2016a, 2016b) and calculated tendon lengths for the mean, lower, and upper bounds of muscles for Panthera atrox.

\begin{tabular}{cccccccc}
\hline Muscle & Slope & $\begin{array}{c}\text { Lower } \\
\text { Limit }\end{array}$ & $\begin{array}{c}\text { Upper } \\
\text { Limit }\end{array}$ & Intercept & Mean & Lower & Upper \\
\hline Serratus dorsalis cranialis & 1.35 & 0.217 & 8.42 & -3.772 & 0.228 & 0.001 & $5.43 \times 10^{5}$ \\
Serratus dorsalis caudalis & -1.53 & -6.001 & -0.389 & 0.484 & 0.001 & 0.000 & 0.382 \\
\hline
\end{tabular}




\section{APPENDIX 12.}

Scaling equations for the vertebral muscles from Cuff et al. (2016a, 2016b) and calculated muscle belly masses for the mean, lower, and upper bounds of muscles for Panthera atrox.

\begin{tabular}{lccccccc}
\hline \multicolumn{1}{c}{ Muscle } & Slope & $\begin{array}{c}\text { Lower } \\
\text { Limit }\end{array}$ & $\begin{array}{c}\text { Upper } \\
\text { Limit }\end{array}$ & Intercept & Mean & Lower & Upper \\
\hline Rectus capitis & 0.679 & 0.472 & 0.977 & -2.58 & 0.098 & 0.032 & 0.480 \\
Splenius cervicis & 1.04 & 0.785 & 1.39 & -2.86 & 0.366 & 0.092 & 2.31 \\
Serratus dorsalis cranialis & 1.00 & 0.523 & 1.93 & -3.23 & 0.124 & 0.009 & 17.1 \\
Serratus dorsalis caudalis & 0.893 & 0.701 & 1.14 & -3.17 & 0.080 & 0.029 & 0.294 \\
Semispinalis capitis biventer & 1.05 & 0.899 & 1.24 & -2.93 & 0.325 & 0.143 & 0.9 \\
Semispinalis capitis complexus & 1.13 & 0.854 & 1.51 & -3.12 & 0.325 & 0.073 & 2.38 \\
Spinalis cervicis & 0.992 & 0.532 & 1.85 & -2.77 & 0.336 & 0.029 & 32.4 \\
Spinalis thoracis & 1.26 & 0.941 & 1.69 & -2.98 & 0.877 & 0.160 & 8.52 \\
Longissimus capitis & 0.867 & 0.488 & 1.54 & -3.21 & 0.064 & 0.008 & 2.32 \\
Longissimus cervicis & 0.673 & 0.338 & 1.34 & -2.40 & 0.143 & 0.024 & 4.98 \\
Longissimus thoracis & 0.821 & 0.542 & 1.24 & -1.94 & 0.916 & 0.207 & 8.76 \\
Iliocostalis thoracis & 0.899 & 0.743 & 1.09 & -2.79 & 0.195 & 0.085 & 0.533 \\
Multifidis throacis & 0.893 & 0.784 & 1.02 & -2.52 & 0.355 & 0.198 & 0.690 \\
Longis. lumborum & 1.26 & 0.652 & 2.43 & -2.55 & 2.34 & 0.092 & 1230 \\
Iliocost. lumborum & 1.19 & 0.860 & 1.65 & -2.58 & 1.49 & 0.258 & 17.0 \\
Multifid. lumborum & 0.942 & 0.705 & 1.26 & -2.60 & 0.381 & 0.108 & 2.05 \\
\hline
\end{tabular}

\section{APPENDIX 13.}

Scaling equations for the vertebral muscles from Cuff et al. (2016a, 2016b) and calculated tendon masses for the mean, lower, and upper bounds of muscles for Panthera atrox . Longis. $=$ longissimus, Iliocost. $=$ iliocostalis, Multifid. $=$ multifidus.

\begin{tabular}{cccccccc}
\hline Muscle & Slope & $\begin{array}{c}\text { Lower } \\
\text { Limit }\end{array}$ & $\begin{array}{c}\text { Upper } \\
\text { Limit }\end{array}$ & Intercept & Mean & Lower & Upper \\
\hline Serratus dorsalis cranialis & 1.36 & 0.609 & 3.03 & -4.63 & 0.033 & 0.001 & 247.5 \\
Serratus dorsalis caudalis & 1.40 & 0.639 & 3.06 & -4.94 & 0.020 & 0.000 & 141.3 \\
\hline
\end{tabular}

